\title{
Recent glacier mass balance and area changes in the Kangri Karpo Mountains from DEMs and glacier inventories
}

\author{
Kunpeng $\mathrm{Wu}^{1,2, *}$, Shiyin $\mathrm{Liu}^{2,3, *}$, Zongli Jiang ${ }^{4}$, Junli $\mathrm{Xu}^{5}$, Junfeng $\mathrm{Wei}^{4}$, and Wanqin $\mathrm{Guo}^{3}$ \\ ${ }^{1}$ School of Resources and Environment, Anqing Normal University, Anqing, 246133, China \\ ${ }^{2}$ Institute of International Rivers and Eco-Security, Yunnan University, Kunming, 650091, China \\ ${ }^{3}$ State key Laboratory of Cryospheric Sciences, Northwest Institute of Eco-Environment and Resources, \\ Chinese Academy of Sciences, Lanzhou, 730000, China \\ ${ }^{4}$ Department of Geography, Hunan University of Science and Technology, Xiangtan, 411201, China \\ ${ }^{5}$ Department of Surveying and Mapping, Yancheng Teachers University, Yancheng, 224007 China \\ *These authors contributed equally to this work.
}

Correspondence: Shiyin Liu (liusy@1zb.ac.cn) and Kunpeng Wu (wukunpeng2008@1zb.ac.cn)

Received: 30 July 2017 - Discussion started: 7 September 2017

Revised: 27 November 2017 - Accepted: 1 December 2017 - Published: 12 January 2018

\begin{abstract}
Due to the influence of the Indian monsoon, the Kangri Karpo Mountains in the south-east of the Tibetan Plateau is in the most humid and one of the most important and concentrated regions containing maritime (temperate) glaciers. Glacier mass loss in the Kangri Karpo is an important contributor to global mean sea level rise, and changes run-off distribution, increasing the risk of glaciallake outburst floods (GLOFs). Because of its inaccessibility and high labour costs, information about the Kangri Karpo glaciers is still limited. Using geodetic methods based on digital elevation models (DEMs) derived from 1980 topographic maps from the Shuttle Radar Topography Mission (SRTM) (2000) and from TerraSAR-X/TanDEM-X (2014), this study has determined glacier elevation changes. Glacier area and length changes between 1980 and 2015 were derived from topographical maps and Landsat TM/ETM+/OLI images. Results show that the Kangri Karpo contained 1166 glaciers with an area of $2048.50 \pm 48.65 \mathrm{~km}^{2}$ in 2015 . Ice cover diminished by $679.51 \pm 59.49 \mathrm{~km}^{2}(24.9 \pm 2.2 \%)$ or $0.71 \pm 0.06 \% \mathrm{a}^{-1}$ from 1980 to 2015 , although nine glaciers advanced. A glacierized area of $788.28 \mathrm{~km}^{2}$, derived from DEM differencing, experienced a mean mass loss of $0.46 \pm$ $0.08 \mathrm{mw}$.e. $\mathrm{a}^{-1}$ from 1980 to 2014 . Shrinkage and mass loss accelerated significantly from 2000 to 2015 compared to 1980-2000, consistent with a warming climate.
\end{abstract}

\section{Introduction}

Glaciers on the Tibetan Plateau (TP) feed many rivers and lakes (Immerzeel et al., 2010), are key components in the cryosphere system (Li et al., 2008) and their mass balance is a useful indicator of climate variability (Oerlemans, 1994; T. Yao et al., 2012). Under recent warming climate, many mountain glaciers have lost mass and receded (IPCC, 2013). However, some positive mass balances have been reported in the central Karakoram, eastern Pamir and the western TP (Bao et al., 2015; Gardelle et al., 2012b, 2013; Kääb et al., 2015; Neckel et al., 2014; T. Yao et al., 2012). How mass balance relates to climate change, water supply and the risk of glacier-related disasters is the subject of much current research.

Glaciers in the Kangri Karpo mountain range are temperate, receiving abundant precipitation from the Indian monsoon (Li et al., 1986; Shi and Liu, 2000). They experienced a substantial reduction in area and length from 1980 to 2013 and a mass deficit from 2005 to 2009 (Li et al., 2014; Yang et al., 2010, 2008; T. Yao et al., 2012), based on inventories from maps and remote sensing or field measurements. While previous studies showed some glaciers advancing in the Kangri Karpo, aerial photographs, CBERS (China-Brazil Earth Resources Satellite) and Landsat Thematic Mapper (TM) images revealed that about $60 \%$ of the glaciers in the region were losing mass from 1980 to 2001 (Liu et al., 2006). Shi 
et al. (2006) attributed the former unexpected glacier dynamics to increased precipitation suppressing glacier melt.

While previous studies agreed that glaciers in the Kangri Karpo were losing mass, the results differed from each other. Using SRTM (Shuttle Radar Topography Mission) and SPOT5 DEMs (24 November 2011), Gardelle et al. (2013) found a mean thinning of $0.39 \pm 0.16 \mathrm{ma}^{-1}$, whereas Kääb et al. (2015), Neckel et al. (2014) and Gardner et al. (2013), using ICESat and SRTM, recorded thinnings of $1.34 \pm 0.29$, $0.81 \pm 0.32$ and $0.30 \pm 0.13 \mathrm{~m} \mathrm{a}^{-1}$ respectively from 2003 to 2009.

Glaciological, hydrological and geodetic methods have been used to determine the mass balance of a glacier (Ye et al., 2015), but the high altitude and harsh climatic conditions of the Kangri Karpo makes fieldwork very difficult. Fortunately, satellite remote sensing has become a promising alternative, even in remote mountainous terrain, for assessing several glaciers at the same time (Paul and Haeberli, 2008). Most glaciers have been now been mapped from aerial photographs taken in October 1980 and subsequently by Xband SAR interferometry (InSAR) in February 2000 (during the SRTM), resulting in a digital elevation model (DEM). Single-pass X-band InSAR from TerraSAR-X on 18 February 2014 and 13 March 2014, together with TanDEM-X digital elevation measurements, provided the basis for another map (Krieger et al., 2007). In this study, differential synthetic aperture radar interferometry (DInSAR) has been used to estimate glacier mass balance in the Kangri Karpo between 1980 and 2014.

\section{Study area}

The Kangri Karpo mountain range in south-eastern Tibet lies at the eastern end of the Nyainqentanglha mountains, extending about $280 \mathrm{~km}$ from north-west to south-east, south of Bomê County and near Motuo, Zayü and Basu counties (Fig. 1). North of this region is the Purlung Tsangpo river, a tributary of the Yarlung Tsangpo River, while on the other side flows the Gongri-Gabo river, part of the western tributary of the Zayü River. This eastern section is exposed to the moist south-western monsoon (Li et al., 1986), which enters the plateau at the grand bend of the Yarlung Tsangpo, where the terrain forces the air to rise. During winter and spring, the westerly jet in the Northern Hemisphere is blocked by the Tibetan Plateau and splits in two; the southern branch forms a trough in the study area after bypassing the Himalayas. Moisture from the Bay of Bengal is attracted to this trough, landing on the TP and resulting in heavy snowfalls. It is the most humid region of Tibetan Plateau and one of the most important and concentrated regions of maritime (temperate) glacier development (Shi and Liu, 2000; Shi et al., 2008a).

It is estimated that the mean summer air temperature at the equilibrium-line altitude (ELA) of glaciers is usually above $1{ }^{\circ} \mathrm{C}$, and annual precipitation is $2500-3000 \mathrm{~mm}$ (Shi et al.,
1988). Most glaciers are at the pressure-melting point, surface ablation is intense and glacier velocity is rapid ( $\mathrm{Li}$ et al., 1986). With high accumulation and ablation rates, the glacier mass turnover is large.

According to the first Chinese Glacier Inventory, the Kangri Karpo contains 1320 glaciers with a total area and volume of $2655.2 \mathrm{~km}^{2}$ and $260.3 \mathrm{~km}^{3}$ (Mi et al., 2002). Yalong Glacier (CGI code: 5O282B37) is the largest $\left(191.4 \mathrm{~km}^{2}\right.$ in area and $32.5 \mathrm{~km}$ in length), while the Ata Glacier (CGI code: $5 \mathrm{O} 291 \mathrm{~B} 181 ; 13.75 \mathrm{~km}^{2}$ in area and $16.7 \mathrm{~km}$ in length), on the south slope of the Kangri Karpo, has the lowest terminus at $2450 \mathrm{~m}$ a.s.l. (Liu et al., 2006). Comparisons of photographs, taken at different times, show that the snout position, ice volume and surface characteristics of Ata Glacier have changed greatly over the past decades (Yang et al., 2008).

\section{Data}

\subsection{Topographic maps}

Five topographic maps at a scale of $1: 100000$ and 50 at $1: 50000$ compiled from aerial photos taken in October 1980 by the Chinese Military Geodetic Service were employed in the present study. Using a seven-parameter transformation method, these maps were georeferenced into the 1954 Beijing Geodetic Coordinate System (BJ54: geoid datum level is Yellow Sea mean sea level at Qingdao Tidal Observatory in 1956) and re-projected into the World Geodetic System 1984 (WGS1984)/Earth Gravity Model 1996 (EGM96) (Xu et al., 2013). Contours were digitized manually and then converted into a raster DEM (TOPO DEM) with a $30 \mathrm{~m}$ grid cell using the Thiessen polygon method (Shangguan et al., 2010; Wei et al., 2015b; Zhang et al., 2016a). According to the photogrammetric Chinese National Standard (2008) issued by the Standardization Administration of the People's Republic of China, the nominal vertical accuracy of these topographic maps was within 3-5 $\mathrm{m}$ for flat and hilly areas (with slopes of $<2^{\circ}$ and $2-6^{\circ}$ respectively) and within $8-14 \mathrm{~m}$ for the mountainsides and high mountain areas (with slopes of $6-25^{\circ}$ and $>25^{\circ}$ ). Since the slopes of the most of the glacierized areas in the Kangri Karpo were gentle $\left(\sim 19^{\circ}\right)$, the vertical accuracy of the TOPO DEM on the glaciers is better than $9 \mathrm{~m}$.

\subsection{Shuttle Radar Topography Mission}

The SRTM acquired interferometric synthetic aperture radar (InSAR) data simultaneously in both the C- and X-band frequencies from 11 to 22 February 2000 (Farr et al., 2007). The SRTM DEM can refer to the glacier surface in the last balance year (1999) with slight seasonal variances (Gardelle et al., 2013; Pieczonka et al., 2013; Zwally et al., 2011). The X-band SAR system had a swath width of $45 \mathrm{~km}$, leaving large data gaps in the resulting X-band DEM (Rabus et al., 2003). Unfortunately, only $23 \%$ of the Kangri Karpo glaciers are covered by the data set. The unfilled finished SRTM C- 


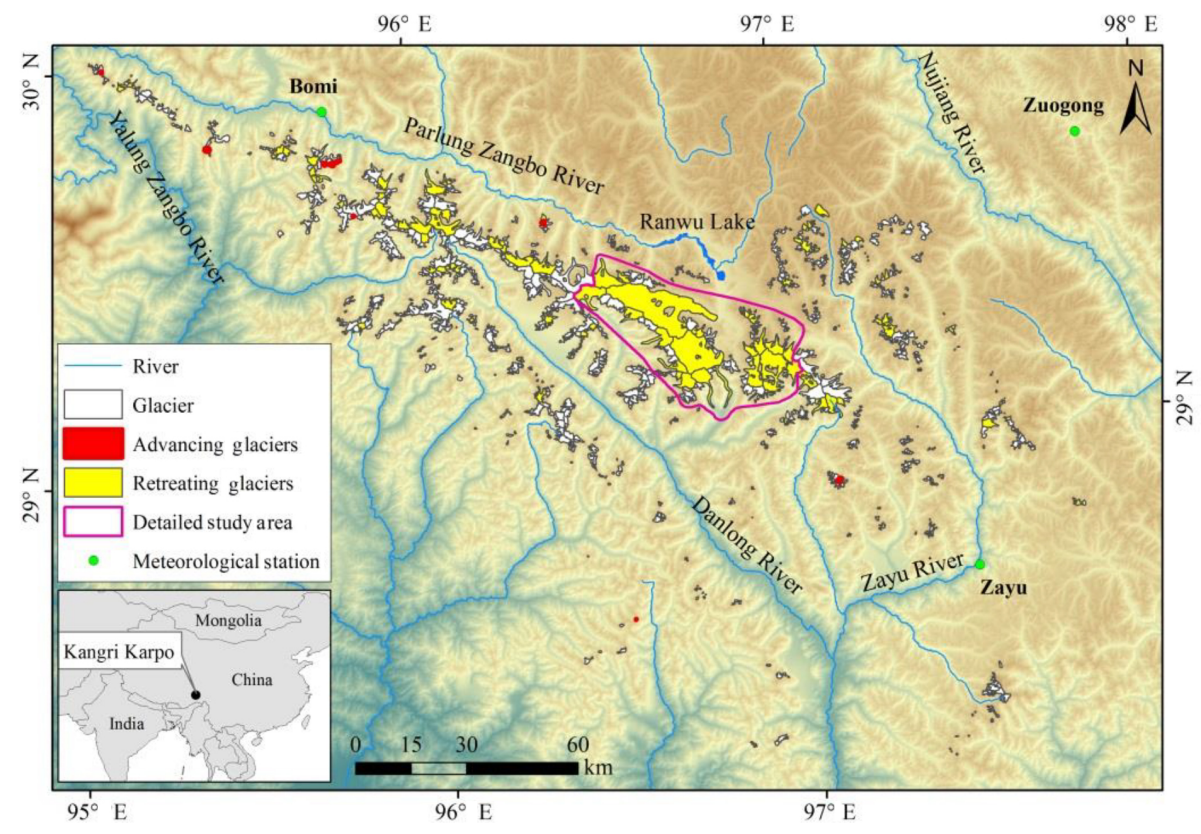

Figure 1. Study area and glacier distribution, including an outline of the detailed study area and meteorological stations. 96 glaciers were selected to generate centre lines and calculate length change, and then categorized as advancing glaciers or retreating glaciers.

band DEM, with a swath width of $225 \mathrm{~km}$ and 1 arc-second resolution (approximately $30 \mathrm{~m}$ ) in WGS84/EGM96, is available at http://earthexplorer.usgs.gov/; it was used to study ice surface elevation change.

\subsection{TerraSAR-X/TanDEM-X}

TerraSAR-X was launched in June 2007 by the German Aerospace Center (DLR). TerraSAR-X and its add-on for digital elevation measurements (TanDEM-X) fly in a close orbit formation to act as a flexible single-pass SAR interferometer (Krieger et al., 2007). Interferometric data can be acquired in the pursuit monostatic mode, the bistatic mode and the alternating bistatic mode. The current baseline for operational DEM generation is the bistatic mode, which minimizes temporal decorrelation and makes efficient use of the transmit power (Krieger et al., 2007).

The experimental Co-registered Single-look Slant-range Complex (CoSSC) files, acquired in bistatic InSAR stripmap mode on 18 February 2014 and 13 March 2014, were employed in this study (Fig. 2 and Table 1). The CoSSC files were focused and co-registered at the TanDEM-X processing and archiving facility (PAF). GAMMA SAR and interferometric processing software were employed for interferometric processing of the CoSSC files (Werner et al., 2000).

\subsection{Landsat images}

Two Landsat Thematic Mapper (TM) scenes, one Landsat Enhanced Thematic Mapper Plus (ETM+) scene and three Landsat Operational Land Imager (OLI) scenes were used to analyse the relationship between glacier mass balance and changes in glacier extent (Table 1). All images are available from the United States Geological Survey (USGS) and are orthorectified with SRTM and ground-control points from the Global Land Survey 2005 (GLS2005) data set. Almost no horizontal shift was observed amongst the Landsat images, the co-registered TerraSAR-X coherence image, the SRTM$\mathrm{X}$ DEM and topographic maps. For Landsat ETM+/OLI images, pan-sharpening employing principal-component analysis was performed to enhance the spatial resolution to $15 \mathrm{~m}$.

\section{Methods}

\subsection{Glacier inventory}

The outlines of glaciers in October 1980 were delineated manually from topographic maps. These maps were georeferenced and rectified with a kilometre grid, and validated by reference to the original aerial photographs to update the first Chinese Glacier Inventory (Wu et al., 2016).

For the Kangri Karpo, glacier outlines were taken from the Second Chinese Glacier Inventory (CGI2), derived from Landsat TM images of 8 September 2005 (Guo et al., 2015). An inventory of high-mountain Asian glaciers, Glacier Area Mapping for Discharge from the Asian Mountains (GAMDAM), was compiled from 356 Landsat ETM+ scenes in 226 path-row sets (Nuimura et al., 2015). The outlines are nearly all from 1999 to 2003 , thus conforming to the recommendation that glacier inventories are based on imagery as close to 2000 as possible (Arendt et al., 2015; Paul et al., 


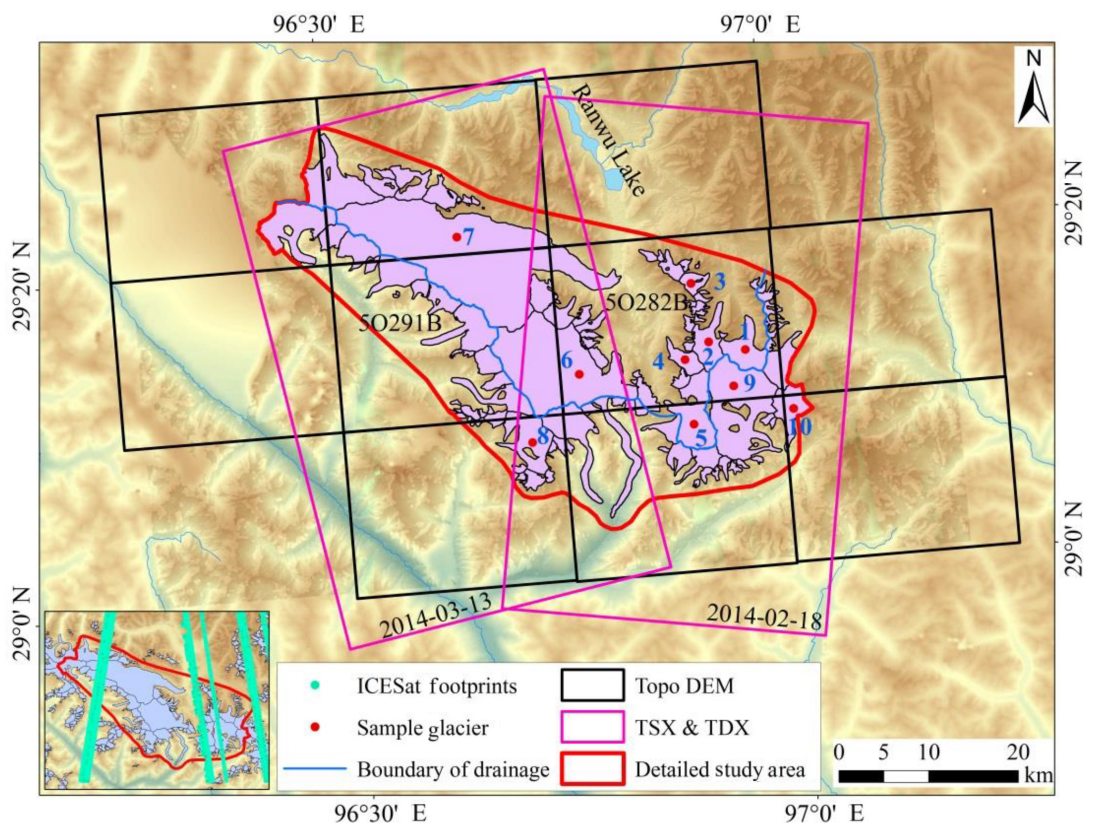

Figure 2. TOPO DEMs, TSX/TDX acquisitions and ICESat footprints. Numbers indicate specific sample glaciers. 5O282B and 5O291B are the drainage basins on the northern and southern slopes of the Kangri Karpo.

Table 1. Overview of satellite images and data sources.

\begin{tabular}{|c|c|c|c|c|}
\hline Date & Source & ID & Pixel size (m) & Utilization \\
\hline Oct 1980 & $\begin{array}{l}\text { Topographic } \\
\text { maps }\end{array}$ & - & 12 & $\begin{array}{l}\text { Glacier identification } \\
\text { for } 1980\end{array}$ \\
\hline Oct 1980 & TOPO DEM & $\begin{array}{l}\mathrm{H} 47 \mathrm{e} 016002 / \mathrm{H} 47 \mathrm{e} 017002 / \mathrm{H} 47 \mathrm{e} 018002 \\
\mathrm{H} 47 \mathrm{e} 016003 / \mathrm{H} 47 \mathrm{e} 017003 / \mathrm{H} 47 \mathrm{e} 018003 \\
\mathrm{H} 47 \mathrm{e} 016004 / \mathrm{H} 47 \mathrm{e} 017004 / \mathrm{H} 47 \mathrm{e} 018004 \\
\mathrm{H} 47 \mathrm{e} 016005 / \mathrm{H} 47 \mathrm{e} 017005 / \mathrm{H} 47 \mathrm{e} 018005\end{array}$ & 30 & $\begin{array}{l}\text { Estimation of glacier } \\
\text { elevation change }\end{array}$ \\
\hline 18 Dec 2001 & Landsat TM & LT51340402001352BJC00 & 30 & Validate and update the \\
\hline 3 Jan 2002 & Landsat TM & LT51340402002003BJC00 & 30 & $\begin{array}{l}\text { GAMDAM and CGI2 } \\
\text { inventory }\end{array}$ \\
\hline 23 Oct 2001 & Landsat ETM+ & LE71340402001296SGS00 & 15 & \\
\hline 11-22 Feb 2000 & SRTM C-band & - & 30 & $\begin{array}{l}\text { Estimation of glacier } \\
\text { elevation change }\end{array}$ \\
\hline 29 Sep 2015 & Landsat OLI & LC81330402015272LGN00 & 15 & Glacier identification \\
\hline 6 Oct 2015 & Landsat OLI & LC81340402015279LGN00 & 15 & for 2015 \\
\hline $25 \mathrm{Jul} 2015$ & Landsat OLI & LC81350392015206LGN00 & 15 & \\
\hline 18 Feb 2014 & TSX/TDX & TDM1_SAR_COS_BIST_SM_S_SRA_ & 12 & Estimation of glacier \\
\hline 13 Mar 2014 & TSX/TDX & $\begin{array}{l}\text { 20140313T113609_20140313T113617 } \\
\text { TDM1_SAR_COS_BIST_SM_S_SRA_ } \\
\text { 20140313T113609_20140313T113617 }\end{array}$ & 12 & elevation change \\
\hline
\end{tabular}

2009). Landsat TM/ETM+ scenes were then used to validate and update the CGI2 and GAMDAM glacier inventories and generate a year 2000 inventory of the study area.

A semi-automated approach, using the TM3/TM5 band ratio, was applied to delineate glacier outlines in 2015 using Landsat OLI images (Bolch et al., 2010b; Paul et al.,
2009; Racoviteanu et al., 2009). To ensure that ice patches were larger than $0.01 \mathrm{~km}^{2}$, a $3 \times 3$ median filter was applied to eliminate isolated pixels (Bolch et al., 2010b; Wu et al., 2016). The derived glacier polygons were checked manually against images from adjacent years with little or no snow and cloud, to discriminate proglacial lakes, seasonal 

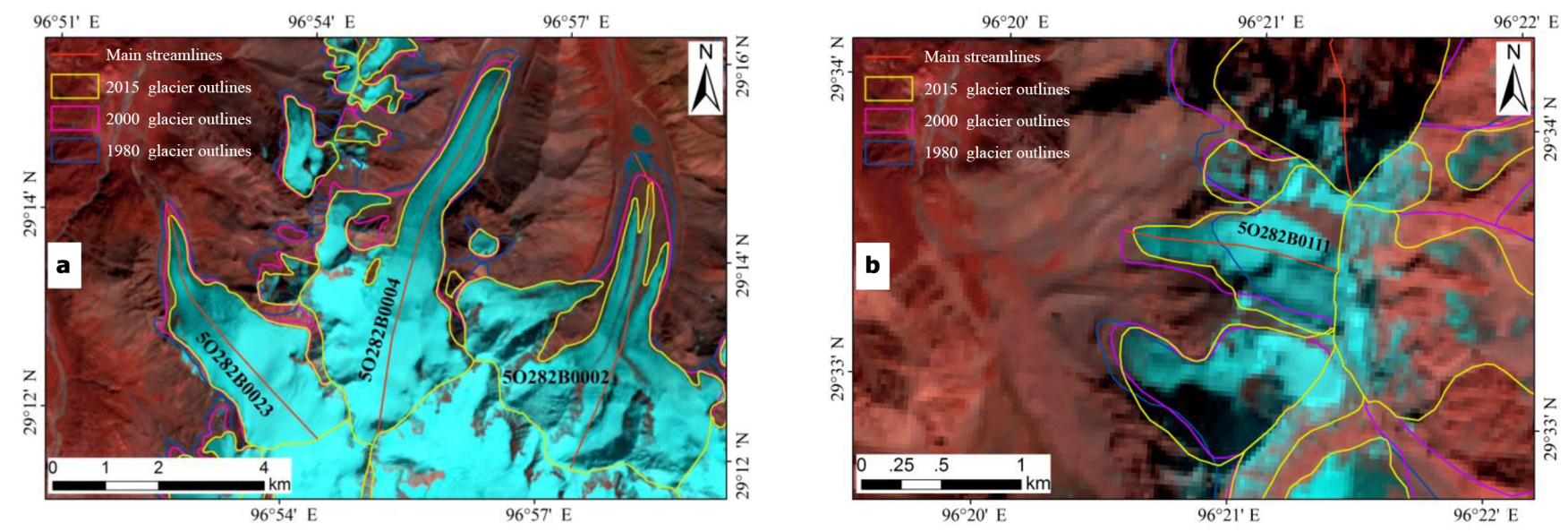

Figure 3. Glacier outlines derived from imagery collected in 1980, 2001-2002 and 2015. The background image is a Landsat OLI image (6 October 2015). (a) Example of glacier retreat. (b) Example of glacier advance.

snow, supraglacial boulders and debris-covered ice (Fig. 3). The final contiguous ice coverage was divided into individual glacier polygons using topographical ridgelines (TRLs), generated automatically from the SRTM-C DEM (Guo et al., 2011).

The best way to assess the accuracy of glacier outlines is to compare compiled results with independently digitized glacier outlines using high-resolution air photos from random locations (Bolch et al., 2010a; Paul et al., 2003). Previous studies showed that average offsets between glacier outlines derived from topographic maps and Corona images were $\pm 6.8 \mathrm{~m}$ (Wu et al., 2016), while between Landsatimage outlines and real-time kinematic differential GPS (RTK-DGPS) measurements, and Google EarthTM images with a spatial resolution better than $1 \mathrm{~m}$, they were \pm 10 and $\pm 30 \mathrm{~m}$ for the delineation of clean and debris-covered ice respectively (Guo et al., 2015). On the basis of these average offsets, mean relative errors of $\pm 1.3, \pm 2.0$ and $\pm 2.4 \%$ were calculated for glacier areas in 1980, 2000 and 2015 respectively.

\subsection{Glacier length}

Glacier length is a key inventory parameter and its vector representation (glacier centre line) is important for modelling future glacier evolution and calculating ice volume (Le Bris and Paul, 2013). Some define it as the central flow line from the highest glacier elevation to the terminus, whereas to others it is the longest flow line (Kienholz et al., 2014; Leclercq et al., 2014). Length change can either be calculated by intersecting the central flow line with the respective glacier outline (Paul and Svoboda, 2009) or by determining the average length of the intersection of the glacier outline with stripes drawn parallel to the main flow direction (Koblet et al., 2010).
In this study, a new method based on an axis concept derived from the glacier's shape was applied, requiring only the glacier outline and the DEM as input (Yao et al., 2015). The glacier-axis concept assumes that the main direction of any given glacier can be defined as a curved line. The glacier outline is initially divided into two curved lines based on its highest and lowest elevations. Using these, the glacier polygon is then divided by Euclidean distance into two regions. The common boundary of these two regions is the glacier axis or glacier centre line. An error estimation of the resulting centre lines was performed, comparing the semiautomatically generated results to high-resolution aerial imagery at the terminus. A Corona image, with a resolution of $4 \mathrm{~m}$, and Google EarthTM images, with a resolution better than $1 \mathrm{~m}$, were used to evaluate the accuracy of these centre lines. In a comparison with topographic maps and Landsat images, the uncertainties in the centre line location were no more than 6 and $7.5 \mathrm{~m}$ respectively.

\subsection{Glacier elevation changes}

The TerraSAR-X/TanDEM-X acquisitions were processed by differential SAR interferometry (DInSAR) (Neckel et al., 2013) using GAMMA SAR and interferometric processing software (Werner et al., 2000).

The interferometric phase of the single-pass TerraSAR$\mathrm{X} /$ TanDEM-X interferogram can be described by

$\Delta_{\varnothing \mathrm{TSX} / \mathrm{TDX}}=\Delta_{\varnothing \text { orbit }}+\Delta_{\varnothing \mathrm{topo}}+\Delta_{\varnothing \mathrm{atm}}+\Delta_{\varnothing \text { scat }}$,

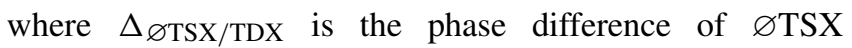
and $\varnothing \mathrm{TDX}$ simultaneously acquired by TerraSAR-X and TanDEM-X, $\Delta_{\varnothing}$ orbit is that from the different acquisition geometry of the SAR sensors, and $\Delta_{\varnothing \text { topo }}$ is from topography. $\Delta_{\varnothing \text { atm }}$ and $\Delta_{\varnothing \text { scat }}$ are the phase differences introduced by atmospheric conditions and different scattering on the ground. As the TerraSAR-X/TanDEM-X data were acquired simul- 
taneously, the same atmospheric conditions and scattering could be assumed for both SAR antennas, thus setting $\Delta_{\varnothing \mathrm{atm}}$

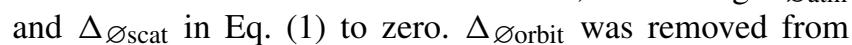
the interferogram by subtracting a simulated flat-earth phase trend (Rosen et al., 2000).

The DInSAR approach can be described by

$\Delta_{\varnothing \mathrm{diff}}=\Delta_{\varnothing \mathrm{TSX} / \mathrm{TDX}}-\Delta_{\varnothing \mathrm{SRTM}-\mathrm{C}}$,

where $\triangle \varnothing$ SRTM-C is the February 2000 SRTM-C interferometric phase. Lacking the raw interferometric data, $\triangle \varnothing$ SRTM-C was simulated from SRTM-C DEM data using the satellite geometry and a baseline model of the TerraSAR$\mathrm{X} /$ TanDEM-X pass. Thus the differential phase $\Delta_{\varnothing \text { diff is }}$ based solely on changes in $\Delta_{\varnothing \text { topo }}$ between data acquisitions (Neckel et al., 2013).

To improve the phase-unwrapping procedure and minimize errors, the unfilled, finished, SRTM C-band DEM was employed. Before generating the differential interferogram, precise horizontal offset registration and fitting between the SRTM C-band DEM and the TerraSAR-X/TanDEM-X acquisitions is required. Based on the relation between the map coordinates of the SRTM C-band DEM segment covering the TerraSAR-X/TanDEM-X master file and the SAR geometry of the respective master file, an initial look-up table was calculated. While the areas of radar shadows and layover in the TerraSAR-X/TanDEM-X interferogram would introduce gaps in the look-up table, a method of linear interpolation between the gap edges in each line of the look-up table was used to fill these gaps. The offsets between the master scene and the simulated intensity of the SRTM C-band DEM were calculated using cross-correlation optimization of the simulated SAR images by employing GAMMA's offset_pwrm module. The horizontal registration and geocoding look-up table were refined by these offsets. The SRTM C-band DEM was translated from geographic coordinates into SAR coordinates via the refined geocoding look-up table, and conversely, the final difference map was translated from SAR coordinates into geographic coordinates. Then a differential interferogram was generated by the TerraSAR-X/TanDEM$\mathrm{X}$ interferogram and the simulated phase of the co-registered SRTM C-band DEM. An adaptive filtering approach was used to filter the differential interferogram (Goldstein and Werner, 1998). GAMMA's minimum cost flow (MCF) algorithm was then employed to unwrap the flattened differential interferogram. According to the computed phase-toheight sensitivity and select ground-control points (GCPs) from respective off-glacier pixel locations in the SRTM Cband DEM, the unwrapped differential phase was converted to absolute differential heights. While a residual not covered by the baseline refinement would exist, it can be regarded as a linear trend estimated by a two-dimensional first-order polynomial fit in off-glacier regions. The linear trend and a constant vertical offset were removed from the maps of absolute differential heights. Finally, the resulting data sets were translated to a metric cartographic coordinate system with $30 \mathrm{~m} \times 30 \mathrm{~m}$ pixel spacing (Neckel et al., 2013). The same DInSAR method was employed to acquire the glacier elevation change from 1980 to 2014 with the data from the TOPO DEM and TerraSAR-X/TanDEM-X acquisitions.

For changes in glacier elevation from 1980 to 1999, common DEM differencing with the TOPO and SRTM C-band DEMs was used to construct a difference map (Bolch et al., 2011; Nuth and Kääb, 2011; Pieczonka et al., 2013; Wei et al., 2015a). Relative horizontal and vertical distortions between the two data sets can be corrected with statistical approaches based on the relationship between elevation difference, slope and aspect (Nuth and Kääb, 2011). Elevation differences in off-glacier regions were used to analyse the consistency of the TOPO and SRTM C-band DEMs (Fig. 4). After co-registration, histogram statistics of the elevation differences for off-glacier regions showed that elevation difference in off-glacier regions concentrated on the mean elevation difference from 4.94 to $0.67 \mathrm{~m}$. It is concluded that elevation difference in off-glacier regions have stabilized and that the pre-processed DEMs were suitable for the estimation of changes in glaciers mass balance. Outliers of elevation differences with values exceeding $\pm 100 \mathrm{~m}$, usually around data gaps and near DEM edges, were omitted (Berthier et al., 2010; Bolch et al., 2011). The vertical biases and horizontal displacements could be adjusted simultaneously using the substantial cosinusoidal relationship between standardized vertical bias and topographical parameters (slope and aspect). Biases caused by different spatial resolutions between the DEMs could be adjusted by the relationship between elevation differences and maximum curvatures (Gardelle et al., 2012a; Nuth and Kääb, 2011).

The penetration depth of the SRTM C-band radar beam into snow and ice needs to be considered when assessing glacier elevation changes (Berthier et al., 2006; Gardelle et al., 2012a; Pieczonka et al., 2013). The penetration depth can range from 0 to $10 \mathrm{~m}$ depending on a variety of parameters such as snow temperature, density and water content (Berthier et al., 2006; Dall et al., 2001). As a first approximation, because the penetration depth of the SRTM X-band radar beam is much smaller than the C-band, the elevation difference between these two values can be considered to be the SRTM C-band radar beam penetration into snow and ice (Gardelle et al., 2012a). Differences between the SRTM Cand X-bands showed an average $1.24 \mathrm{~m} \mathrm{C}$-band penetration depth in the Kangri Karpo. The mean value is in agreement with Gardelle et al. (2013), who found a penetration of $1.7 \mathrm{~m}$ in the eastern Nyainqentanglha mountains, which they called the Hengduan Shan.

\subsection{Mass balance and error estimation}

In order to convert derived surface-elevation changes into glacier mass balance the ice/firn/snow density must be considered. A value of $900 \mathrm{~kg} \mathrm{~m}^{-3}$ was applied to assess the water equivalent (w.e.) of mass changes from elevation dif- 

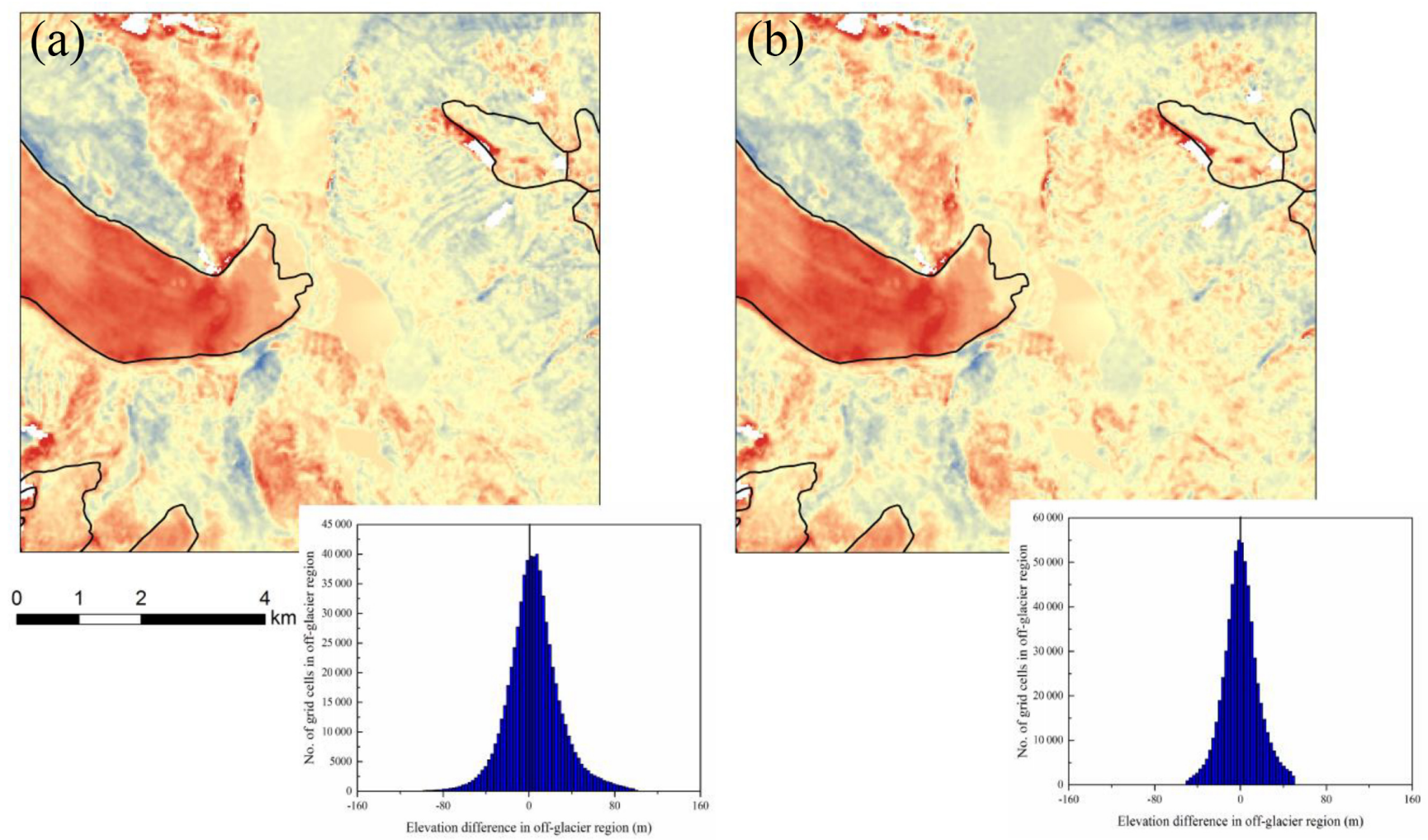

Figure 4. Elevation differences estimated between SRTM and TOPO DEMs before (a) and after (b) co-registration, northern slope of the Kangri Karpo. Location of the data example is shown in Fig. 6a.

ferences, then an ice density uncertainty of $17 \mathrm{~kg} \mathrm{~m}^{-3}$ was added (Gardner et al., 2013; Neckel et al., 2013).

Elevations from the ICESat Geoscience Laser Altimeter System (GLAS) (Neckel et al., 2013) were used to assess the accuracy of the TOPO and SRTM C-band DEMs. These data were obtained from the National Snow and Ice Data Center (NSIDC) (release 634; product GLA 14). Because of the effect of clouds, some GLAS data could not represent the true altitude of the ground. Outliers of elevation differences between GLA 14 and multi-source DEMs in offglacier regions, with values exceeding $\pm 100 \mathrm{~m}$, were removed. Comparisons between the GLAS and the TOPO and SRTM C-band DEMs elevation data yielded a mean and SD of $2.74 \pm 1.73 \mathrm{~m}$ and $2.65 \pm 1.48 \mathrm{~m}$ respectively. The GCPs used to convert the unwrapped TerraSAR-X/TanDEM-X interferogram into absolute heights from off-glacier pixel locations revealed that the vertical biases of the TerraSARX/TanDEM-X DEM and GLA 14 were similar to those of the SRTM C-band DEM and GLA 14.

To estimate the errors of the derived surface-elevation changes, the residual elevation differences in off-glacier regions were estimated assuming that heights in these areas did not change from 1980 to 2014 and that elevations should be equal in TOPO and SRTM C-band DEMs and the TerraSAR$\mathrm{X} /$ TanDEM-X DEM. The mean elevation differences (MED) between the final difference maps in the off-glacier regions ranged from -1.42 to $0.75 \mathrm{~m}$ (Table 2). Because averaging over larger regions reduces the error, the standard deviation (SD) over off-glacier regions will probably overestimate the uncertainty of the larger sample, so the uncertainty can be estimated by the standard error of the mean (SE):

$\mathrm{SE}=\frac{\mathrm{SD}}{\sqrt{N}}$,

where $N$ is the number of the included pixels. To avoid the effect of autocorrelation, a decorrelation length of 600 and $200 \mathrm{~m}$ was employed for difference maps derived by common DEM differencing and DInSAR (Bolch et al., 2011; Neckel et al., 2013). The overall errors of the derived surfaceelevation changes can then be estimated using SE and MED from off-glacier regions:

$\sigma=\sqrt{\mathrm{MED}^{2}+\mathrm{SE}^{2}}$.

Finally, the root of sum of squares of the estimated errors of glacier area and surface elevation changes, as well as the ice density uncertainty of $17 \mathrm{~kg} \mathrm{~m}^{-3}$, were used to estimate overall mass balance errors (Neckel et al., 2013). 
Table 2. Statistics of vertical errors between the TOPO, SRTM and TSX/TDX. MED is mean elevation difference, SD is standard deviation, $N$ is the number of considered pixels, SE is standard error and $\sigma$ is the overall error of the derived surface elevation change.

\begin{tabular}{llrrrrr}
\hline Region & Item & MED $(\mathrm{m})$ & SD $(\mathrm{m})$ & $N$ & SE $(\mathrm{m})$ & $\sigma(\mathrm{m})$ \\
\hline 5O282B basin & SRTM - TOPO & -0.65 & 7.44 & 866 & 0.25 & 0.70 \\
& TSX/TDX - SRTM & -0.90 & 5.83 & 7807 & 0.07 & 0.90 \\
& TSX/TDX - TOPO & -1.42 & 5.07 & 7807 & 0.06 & 1.42 \\
\hline 5O291B basin & SRTM - TOPO & 0.75 & 8.19 & 963 & 0.26 & 0.80 \\
& TSX/TDX - SRTM & 0.07 & 12.68 & 8549 & 0.14 & 0.15 \\
& TSX/TDX - TOPO & 0.71 & 5.50 & 8549 & 0.06 & 0.71 \\
\hline \multirow{2}{*}{ Total } & SRTM - TOPO & 0.67 & 16.41 & 1829 & 0.38 & 0.77 \\
& TSX/TDX - SRTM & -0.42 & 9.93 & 16356 & 0.08 & 0.43 \\
& TSX/TDX - TOPO & -0.53 & 5.36 & 16356 & 0.04 & 0.53 \\
\hline
\end{tabular}

\section{Results}

\subsection{Area change}

According to the 2015 inventory, the Kangri Karpo contains 1166 glaciers with an area of $2048.50 \pm 48.65 \mathrm{~km}^{2}$ and a mean glacier size of $1.76 \pm 0.04 \mathrm{~km}^{2}$ (Fig. 5). The highest number of glaciers are in the size class $0.1-0.5 \mathrm{~km}^{2}$, whereas glaciers between 1 and $5 \mathrm{~km}^{2}$ cover the largest area (Fig. 5a). Only two glaciers are $>50 \mathrm{~km}^{2}$ : the largest is Yalong Glacier $\left(173.00 \pm 0.67 \mathrm{~km}^{2}\right)$ and the other is Xirinongpu Glacier $\left(90.28 \pm 0.23 \mathrm{~km}^{2}\right)$. Glaciers present a normal hypsometry with about $76.9 \%$ of their area lying in the 4500 $5500 \mathrm{~m}$ elevation range. Azha Glacier has the lowest glacier tongue position at $2551 \mathrm{~m}$ a.s.l. (Fig. 5b). The median glacier elevation is around $4852 \mathrm{~m}: 5215 \mathrm{~m}$ for glaciers on the northern slope and $4639 \mathrm{~m}$ for those on the south. This is consistent with the equilibrium-line altitude in the south-eastern Tibetan Plateau (Su et al., 2014). The mean glacier surface slope is $24.1^{\circ}$, with most values in the $12-32^{\circ}$ range, which accounts for $80.5 \%$ of the glaciers and $85.4 \%$ of their area. Most glaciers have a SE, S or SW aspect, accounting for $59.2 \%$ of the glaciers and $80.9 \%$ of their area.

A comparison of the total area in 1980 with that in 2015 shows that glacier cover in the Kangri Karpo declined by $679.51 \pm 59.49 \mathrm{~km}^{2}(24.9 \pm 2.2 \%)$ or $0.71 \pm 0.06 \% \mathrm{a}^{-1}$; a larger percentage of this was represented by the smaller glaciers (Fig. 5c). However, absolute area loss was higher for the larger glaciers. Analysis of the elevation characteristics showed a total loss of the ice cover below $2500 \mathrm{~m}$. The largest absolute area loss was in the $4500-4700 \mathrm{~m}$ a.s.l. range, while the ice cover above $5800 \mathrm{~m}$ remained almost unchanged. The average minimum elevation of the glaciers increased by $106 \mathrm{~m}$, while their median elevation rose about $56 \mathrm{~m}$ from 4796 to $4852 \mathrm{~m}$.

The rate of glacier shrinkage from 1980 to 2000 was lower than from 2000 to 2015 (Table 3). Glacier area decreased by $63.72 \pm 9.06 \mathrm{~km}^{2}$ from $784.60 \mathrm{~km}^{2}(8.1 \pm 1.2 \%)$ or $0.41 \pm$ $0.06 \% \mathrm{a}^{-1}$ between 1980 and 2000. However, from 2000 to
2015 the loss was $56.00 \pm 10.97 \mathrm{~km}^{2}(7.8 \pm 1.5 \%)$ or $0.52 \% \pm$ $0.10 \% \mathrm{a}^{-1}$. A detailed analysis of 10 sample glaciers confirmed that all decreased continuously throughout the investigated periods (Table 4). Percentage area loss for these glaciers between 1980 and 2015 varied from $8.6 \%$ (WGI ID/GLIMS ID: 5O291B0200/G097005E29155N, the smallest loss) to $20.9 \%$ (Parlung Glacier no. 10, the largest loss). In terms of absolute area loss the greatest was $20.43 \mathrm{~km}^{2}$ at Yalong Glacier and the smallest was $1.04 \mathrm{~km}^{2}$ at Parlung Glacier no. 10.

\subsection{Length change}

Comparing the termini of all glaciers from 1980 to 2015 shows that only nine glaciers in the Kangri Karpo advanced while the rest retreated. These nine glaciers experienced a mean advance of $14.8 \mathrm{ma}^{-1}$, with centre line lengths increasing by 103 to $1547 \mathrm{~m}$. The lowering of the terminus elevations of these advancing glaciers averaged $191 \mathrm{~m}$, varying from $34 \mathrm{~m}$ (4796 to $4762 \mathrm{~m}$ a.s.l.) to $412 \mathrm{~m}$ (43623949 m a.s.1.) (Table 5). Based on different glacier size, slope and aspect, 86 glaciers were selected from all the retreating glaciers to analyse the length changes. They experienced a mean recession of $759 \mathrm{~m}\left(21.7 \mathrm{ma}^{-1}\right)$, from 6 to $3956 \mathrm{~m}$.

Like the change in area seen in the Kangri Karpo, accelerated retreat was observed from 1980 to 2000 and from 2000 to 2015, based on measurements of glacier length (Table 6): mean reductions of $21.0 \mathrm{ma}^{-1}$ for the former period (2.5$\left.104.2 \mathrm{ma}^{-1}\right)$ and $22.6 \mathrm{ma}^{-1}\left(1.3-144.8 \mathrm{ma}^{-1}\right)$ for the latter. The retreat of Yalong Glacier slowed from $78.0 \mathrm{ma}^{-1}$ in 1980-2000 to $13.6 \mathrm{ma}^{-1}$ in 2000-2014, while that for Azha Glacier increased significantly over the two periods, from 11.3 to $144.8 \mathrm{~m} \mathrm{a}^{-1}$ respectively.

\subsection{Mass balance}

The average lowering of glacier surfaces in the Kangri Karpo was $-17.46 \pm 0.54 \mathrm{~m}$ from 1980 to 2014 . Glaciers with an area of $788.28 \mathrm{~km}^{2}$ experienced a mean thinning of $0.51 \pm$ 
Table 3. Glacier area changes in the Kangri Karpo from 1980 to 2015.

\begin{tabular}{|c|c|c|c|c|c|c|c|c|}
\hline \multirow[t]{2}{*}{ Year } & \multicolumn{2}{|c|}{ 5O282B basin } & \multicolumn{2}{|c|}{ 5O291B basin } & \multicolumn{2}{|c|}{ Detailed study area } & \multicolumn{2}{|c|}{ Mountain range } \\
\hline & $\begin{array}{c}\text { Area } \\
\left(\mathrm{km}^{2}\right)\end{array}$ & $\begin{array}{l}\text { Change } \\
\left(\% \mathrm{a}^{-1}\right)\end{array}$ & $\begin{array}{c}\text { Area } \\
\left(\mathrm{km}^{2}\right)\end{array}$ & $\begin{array}{l}\text { Change } \\
\left(\% \mathrm{a}^{-1}\right)\end{array}$ & $\begin{array}{c}\text { Area } \\
\left(\mathrm{km}^{2}\right)\end{array}$ & $\begin{array}{l}\text { Change } \\
\left(\% \mathrm{a}^{-1}\right)\end{array}$ & $\begin{array}{c}\text { Area } \\
\left(\mathrm{km}^{2}\right)\end{array}$ & $\begin{array}{l}\text { Change } \\
\left(\% \mathrm{a}^{-1}\right)\end{array}$ \\
\hline 1980 & $470.31 \pm 4.82$ & & $314.28 \pm 4.39$ & & $784.60 \pm 5.02$ & & $2728.00 \pm 34.24$ & \\
\hline $2000 \mathrm{~s}$ & $432.91 \pm 6.31$ & $-0.40 \pm 0.08$ & $287.97 \pm 6.02$ & $-0.42 \pm 0.12$ & $720.88 \pm 7.20$ & $-0.41 \pm 0.06$ & - & - \\
\hline 2015 & $406.67 \pm 6.76$ & $-0.40 \pm 0.14$ & $254.46 \pm 7.25$ & $-0.78 \pm 0.22$ & $664.88 \pm 7.83$ & $-0.52 \pm 0.10$ & $2048.50 \pm 48.65$ & - \\
\hline $1980-2015$ & & $-0.39 \pm 0.05$ & & $-0.54 \pm 0.08$ & & $-0.44 \pm 0.03$ & & $-0.71 \pm 0.06$ \\
\hline
\end{tabular}

Table 4. Area changes for 10 sample glaciers in the Kangri Karpo.

\begin{tabular}{|c|c|c|c|c|c|c|c|c|c|c|c|c|}
\hline \multirow[t]{2}{*}{ ID } & \multirow[t]{2}{*}{ Glacier } & \multirow{2}{*}{$\begin{array}{l}\text { WGI ID/ } \\
\text { GLIMS ID }\end{array}$} & \multirow{2}{*}{$\begin{array}{c}1980 \text { Area } \\
\left(\mathrm{km}^{2}\right)\end{array}$} & \multicolumn{3}{|c|}{ 1980-2000 } & \multicolumn{3}{|c|}{$2000-2015$} & \multicolumn{3}{|c|}{ 1980-2015 } \\
\hline & & & & $\begin{array}{c}\Delta \mathrm{a} \text { abs. } \\
\left(\mathrm{km}^{2}\right)\end{array}$ & $\begin{array}{l}\Delta \text { a rel. } \\
\left(\mathrm{km}^{2}\right)\end{array}$ & $\begin{array}{c}\text { Rate } \\
\left(\% \mathrm{a}^{-1}\right)\end{array}$ & $\begin{array}{c}\Delta \text { a abs. } \\
\left(\mathrm{km}^{2}\right)\end{array}$ & $\begin{array}{c}\Delta \text { a rel. } \\
\left(\mathrm{km}^{2}\right)\end{array}$ & $\begin{array}{c}\text { Rate } \\
\left(\% \mathrm{a}^{-1}\right)\end{array}$ & $\begin{array}{c}\Delta \text { a abs. } \\
\left(\mathrm{km}^{2}\right)\end{array}$ & $\begin{array}{c}\Delta \text { a rel. } \\
\left(\mathrm{km}^{2}\right)\end{array}$ & $\begin{array}{c}\text { Rate } \\
\left(\% \mathrm{a}^{-1}\right)\end{array}$ \\
\hline 1 & Danong & $\begin{array}{l}\text { 5O282B0002/ } \\
\text { G096960E29217N }\end{array}$ & 15.46 & -0.87 & $-5.6 \%$ & $-0.28 \%$ & -1.74 & $-11.9 \%$ & $-0.80 \%$ & -2.61 & $-16.9 \%$ & $-0.48 \%$ \\
\hline 2 & $\begin{array}{l}\text { Parlung no. } \\
4\end{array}$ & $\begin{array}{l}\text { 5O282B0004/ } \\
\text { G096920E29228N }\end{array}$ & 13.52 & -1.56 & $-11.5 \%$ & $-0.58 \%$ & -0.97 & $-8.1 \%$ & $-0.54 \%$ & -2.53 & $-18.7 \%$ & $-0.53 \%$ \\
\hline 3 & $\begin{array}{l}\text { Parlung no. } \\
10\end{array}$ & $\begin{array}{l}\text { 5O282B0010/ } \\
\text { G096904E29286N }\end{array}$ & 4.98 & -0.55 & $-11.1 \%$ & $-0.55 \%$ & -0.49 & $-11.1 \%$ & $-0.74 \%$ & -1.04 & $-20.9 \%$ & $-0.60 \%$ \\
\hline 4 & Zuoqiupu & $\begin{array}{l}\text { 5O282B0023/ } \\
\text { G096891E29212N }\end{array}$ & 7.46 & -0.76 & $-10.2 \%$ & $-0.51 \%$ & -0.43 & $-6.4 \%$ & $-0.43 \%$ & -1.19 & $-15.9 \%$ & $-0.45 \%$ \\
\hline 5 & Bimaque & $\begin{array}{l}\text { 5O282B0025/ } \\
\text { G096897E29157N }\end{array}$ & 26.71 & -1.25 & $-4.7 \%$ & $-0.23 \%$ & -2.45 & $-9.6 \%$ & $-0.64 \%$ & -3.70 & $-13.9 \%$ & $-0.40 \%$ \\
\hline 6 & Xirinongpu & $\begin{array}{l}\text { 5O282B0028/ } \\
\text { G096745E29216N }\end{array}$ & 98.99 & -2.50 & $-2.5 \%$ & $-0.13 \%$ & -6.21 & $-6.4 \%$ & $-0.43 \%$ & -8.71 & $-8.8 \%$ & $-0.25 \%$ \\
\hline 7 & Yalong & $\begin{array}{l}\text { 5O282B0037/ } \\
\text { G096657E29334N }\end{array}$ & 193.43 & -13.27 & $-6.9 \%$ & $-0.34 \%$ & -7.16 & $-4.0 \%$ & $-0.27 \%$ & -20.43 & $-10.6 \%$ & $-0.30 \%$ \\
\hline 8 & I & $\begin{array}{l}\text { 5O291B0151/ } \\
\text { G096711E29143N }\end{array}$ & 19.17 & -0.42 & $-2.2 \%$ & $-0.11 \%$ & -1.43 & $-7.6 \%$ & $-0.51 \%$ & -1.85 & $-9.6 \%$ & $-0.28 \%$ \\
\hline 9 & I & $\begin{array}{l}\text { 5O291B0196/ } \\
\text { G096943E29175N }\end{array}$ & 56.45 & -2.42 & $-4.3 \%$ & $-0.21 \%$ & -6.11 & $-11.3 \%$ & $-0.75 \%$ & -8.54 & $-15.1 \%$ & $-0.43 \%$ \\
\hline 10 & I & $\begin{array}{l}\text { 5O291B0200/ } \\
\text { G097005E29155N }\end{array}$ & 14.66 & -0.31 & $-2.1 \%$ & $-0.10 \%$ & -0.95 & $-6.6 \%$ & $-0.44 \%$ & -1.26 & $-8.6 \%$ & $-0.25 \%$ \\
\hline
\end{tabular}

$0.09 \mathrm{ma}^{-1}$ or a mean mass loss of $0.46 \pm 0.08 \mathrm{mw} . \mathrm{a}^{-1}$, equivalent to an overall mass change of $-13.76 \pm 0.43 \mathrm{Gt}$. The rate of thinning of these glaciers has increased. From 1980 to 2000 , glaciers thinned on average by $5.30 \pm 0.77 \mathrm{~m}$ and experienced a mass loss of $0.24 \pm 0.16 \mathrm{mw}$.e. $\mathrm{a}^{-1}$. Lowering from 2000 to 2014 was $11.04 \pm 0.43 \mathrm{~m}$ with a mass loss of $0.71 \pm 0.10 \mathrm{mw}^{\mathrm{m}} \mathrm{a}^{-1}$ (Fig. 6 and Table 7).

Mass balance in the Kangri Karpo during 1980-2014 was heterogeneous. Glaciers with an area of $471.06 \pm 3.03 \mathrm{~km}^{2}$ in the 50282B drainage basin experienced a greater mass deficit of $0.51 \pm 0.22 \mathrm{mw} . e . \mathrm{a}^{-1}$ from 1980 to 2014 , with means of $0.30 \pm 0.14$ and $0.76 \pm 0.22 \mathrm{mw} . \mathrm{m}^{-1}$ for 1980 2000 and 2000-2014 respectively. The mean deficit of $0.39 \pm$ $0.11 \mathrm{mw}$. e. $\mathrm{a}^{-1}$ in basin $50291 \mathrm{~B}$ was smaller than that in basin 5O282B during 1980-2014. Glaciers with an area of $317.22 \pm 4.27 \mathrm{~km}^{2}$ in basin 5O291B experienced an acceleration in the deficit from 1980 to 2000 and 2000 to 2014, with means of $0.13 \pm 0.16$ and $0.63 \pm 0.04$ mw.e. $\mathrm{a}^{-1}$.

A marked thickening (elevation increase) was observed at the termini of two glaciers (5O291B0113 and 5O291B0117) on the southern slope of the Kangri Karpo (Fig. 6c). Substantial debris cover of 3.79 and $3.70 \mathrm{~km}^{2}$ accounts for 20.6 and $31.4 \%$ of their individual area and 69.4 and $63.3 \%$ of their length. The termini of these glaciers probably remained stable from October 1980 to October 2015 because of this debris cover.

\section{Discussion}

\subsection{Uncertainty}

Uncertainty in the delineation of glacier outlines can be the result of positional and processing errors (Bolch et al., 2010a; Racoviteanu et al., 2009). Seasonal snow, cloud and debris cover complicate the precision of glacier mapping (Paul et al., 2013). The accuracy of the outlines in this study was assessed by comparing them with independently digitized glacier outlines from high-resolution aerial photography. An uncertainty model was developed to assess accuracies estimated in this study (Pfeffer et al., 2014). Using this, a value of $24.33 \mathrm{~km}^{2}$ was determined for glaciers in the Kangri Karpo in 2015. This is smaller than the $48.65 \mathrm{~km}^{2}$ uncertainty assigned in this study. This discrepancy is probably because delineation uncertainties have been overestimated in 
Table 5. Length change of advancing glaciers in the Kangri Karpo. The uncertainties in glacier length in 1980 and 2015 are 6 and $7.5 \mathrm{~m}$, and the uncertainty of length change is $0.27 \mathrm{ma}^{-1}$.

\begin{tabular}{|c|c|c|c|c|c|c|}
\hline \multirow[t]{2}{*}{ WGI ID } & \multicolumn{2}{|c|}{1980} & \multicolumn{2}{|c|}{2015} & \multirow{2}{*}{$\begin{array}{l}\text { Length } \\
\text { change } \\
\left(\mathrm{ma}^{-1}\right)\end{array}$} & \multirow{2}{*}{$\begin{array}{r}\text { Lowering of } \\
\text { terminus } \\
\text { elevation }(\mathrm{m})\end{array}$} \\
\hline & $\begin{array}{r}\text { Length } \\
(\mathrm{m})\end{array}$ & $\begin{array}{r}\text { Terminal } \\
\text { elevation }(\mathrm{m})\end{array}$ & $\begin{array}{r}\text { Length } \\
(\mathrm{m})\end{array}$ & $\begin{array}{r}\text { Terminal } \\
\text { elevation }(\mathrm{m})\end{array}$ & & \\
\hline 5O282B0111 & 762.75 & 5270 & 1300.87 & 4951 & 15.37 & 319 \\
\hline $5 \mathrm{O} 282 \mathrm{~B} 0223$ & 961.93 & 4884 & 1317.09 & 4637 & 10.15 & 247 \\
\hline $5 \mathrm{O} 282 \mathrm{~B} 0225$ & 1244.88 & 4705 & 1793.16 & 4483 & 15.67 & 222 \\
\hline $5 \mathrm{O} 282 \mathrm{~B} 0226$ & 301.13 & 4870 & 648.43 & 4680 & 9.92 & 190 \\
\hline $5 \mathrm{O} 282 \mathrm{~B} 0278$ & 604.73 & 4876 & 707.97 & 4825 & 2.95 & 51 \\
\hline $5 \mathrm{O} 283 \mathrm{~A} 0004$ & 1067.55 & 4361 & 2614.65 & 3949 & 44.20 & 412 \\
\hline 5O283B0022 & 481.76 & 4743 & 625.38 & 4624 & 4.10 & 119 \\
\hline 5O291A0004 & 342.07 & 4796 & 798.15 & 4762 & 13.03 & 34 \\
\hline 5О291B0201 & 4045.77 & 3931 & 5047.28 & 3833 & 28.61 & 98 \\
\hline 5О291B0288 & 1277.50 & 4690 & 1898.78 & 4563 & 17.75 & 127 \\
\hline
\end{tabular}

Table 6. Length change of glaciers in the Kangri Karpo. The uncertainties in glacier length in 1980, 2000s and 2015 are 6, 7.5 and $7.5 \mathrm{~m}$. The uncertainties in length change during the 1980-2000s, 2000s-2015 and 1980-2015 periods are $0.48,0.71$ and $^{0.27} \mathrm{ma}^{-1}$.

\begin{tabular}{|c|c|c|c|c|c|c|}
\hline \multirow[t]{2}{*}{ WGI ID } & \multicolumn{3}{|c|}{ Glacier length (m) } & \multicolumn{3}{|c|}{ Length change $\left(\mathrm{ma}^{-1}\right)$} \\
\hline & 1980 & $2000 \mathrm{~s}$ & 2015 & $\begin{array}{l}1980- \\
2000 \mathrm{~s}\end{array}$ & $\begin{array}{r}2000 s- \\
2015\end{array}$ & $\begin{array}{r}1980- \\
2015\end{array}$ \\
\hline 50282B0002 & 6271.16 & 5773.04 & 5635.20 & 24.91 & 9.19 & 18.17 \\
\hline 5O282B0004 & 7756.96 & 7540.24 & 7375.95 & 10.84 & 10.95 & 10.89 \\
\hline 5О282B0010 & 3167.28 & 2970.05 & 2853.12 & 9.86 & 7.80 & 8.98 \\
\hline 5О282B0013 & 3602.30 & 3119.71 & 2960.66 & 24.13 & 10.60 & 18.33 \\
\hline 5О282B0017 & 1631.20 & 1394.38 & 1261.97 & 11.84 & 8.83 & 10.55 \\
\hline 5O282B0023 & 5517.39 & 5431.23 & 5209.88 & 4.31 & 14.76 & 8.79 \\
\hline $50282 \mathrm{~B} 0025$ & 5357.49 & 4834.03 & 4548.90 & 26.17 & 19.01 & 23.10 \\
\hline 5О282B0028 & 16890.03 & 16228.66 & 15817.24 & 33.07 & 27.43 & 30.65 \\
\hline 5О282B0034 & 3925.35 & 3860.98 & 3832.31 & 3.22 & 1.91 & 2.66 \\
\hline 5O282B0037 & 32868.46 & 31309.45 & 31105.27 & 77.95 & 13.61 & 50.38 \\
\hline 5О282B0081 & 5306.99 & 5212.33 & 4920.24 & 4.73 & 19.47 & 11.05 \\
\hline $50282 \mathrm{~B} 0083$ & 8258.42 & 8102.68 & 7921.12 & 7.79 & 12.10 & 9.64 \\
\hline 5О291B0104 & 8209.80 & 8075.25 & 7922.90 & 6.73 & 10.16 & 8.20 \\
\hline 5О291B0108 & 7570.99 & 7200.65 & 6725.48 & 18.52 & 31.68 & 24.16 \\
\hline 5O291B0113 & 7677.91 & 7627.05 & 7580.98 & 2.54 & 3.07 & 2.77 \\
\hline 5O291B0117 & 15664.48 & 15572.74 & 15456.43 & 4.59 & 7.75 & 5.94 \\
\hline 5O291B0150 & 3509.59 & 2677.17 & 2535.09 & 41.62 & 9.47 & 27.84 \\
\hline 5O291B0151 & 6681.68 & 6329.14 & 6309.40 & 17.63 & 1.32 & 10.64 \\
\hline 5О291B0179 & 13104.49 & 13037.72 & 12473.61 & 3.34 & 37.61 & 18.02 \\
\hline 5О291B0181 & 15536.55 & 15309.66 & 13137.82 & 11.34 & 144.79 & 68.54 \\
\hline 50291B0196 & 9241.01 & 7157.37 & 6812.94 & 104.18 & 22.96 & 69.37 \\
\hline 5O291B0200 & 7698.33 & 7449.66 & 7013.83 & 12.43 & 29.05 & 19.56 \\
\hline 5O291B0372 & 7681.85 & 7236.61 & 6251.62 & 22.26 & 65.67 & 40.86 \\
\hline
\end{tabular}

this study, particularly for debris-covered ice areas and where exposed bedrock is surrounded by an ice cover.

For mass-balance uncertainties, the penetration depth of the SRTM C-band radar beam was critical when the SRTM DEM was used for geodetic mass-balance calculations. This depth can be estimated by comparing the SRTM C- and Xband DEMs (Gardelle et al., 2012a; Kääb et al., 2012). Pre- vious studies indicate the depth decreases as the temperature and water content of the surface snow increases (Surdyk, 2002); penetration depths of $2.1-4.7 \mathrm{~m}$ at $10 \mathrm{GHz}$ were measured in the Antarctic (Davis and Poznyak, 1993). Glaciers in the eastern Nyainqentanglha mountains are predominantly influenced by the monsoon and have more snow moisture and higher temperatures than the Antarctic ice sheet (Shi and 
Table 7. Mean surface elevation changes and mass balance for the single glaciers and different regions in the Kangri Karpo from 1980 to 2014. Glacier area is the geometric union of the 1980, 2000s and 2015 glacier areas. Mean $\Delta H$ is mean surface elevation change and mass balance is the annual mass budgets.

\begin{tabular}{|c|c|c|c|c|c|c|c|c|}
\hline \multirow{2}{*}{\multicolumn{2}{|c|}{ Region }} & \multirow{2}{*}{$\begin{array}{r}\text { Glacier } \\
\text { area } \\
\left(\mathrm{km}^{2}\right)\end{array}$} & \multicolumn{2}{|c|}{$1980-2000$} & \multicolumn{2}{|c|}{$2000-2014$} & \multicolumn{2}{|c|}{ 1980-2014 } \\
\hline & & & $\begin{array}{r}\text { Mean } \\
\Delta H(\mathrm{~m})\end{array}$ & $\begin{array}{r}\text { Mass balance } \\
\left(\mathrm{m} \text { w.e. } \mathrm{a}^{-1}\right)\end{array}$ & $\begin{array}{r}\text { Mean } \\
\Delta H(\mathrm{~m})\end{array}$ & $\begin{array}{r}\text { Mass balance } \\
\left(\mathrm{m} \text { w.e. } \mathrm{a}^{-1}\right)\end{array}$ & $\begin{array}{r}\text { Mean } \\
\Delta H(\mathrm{~m})\end{array}$ & $\begin{array}{r}\text { Mass balance } \\
\left(\mathrm{m} w . e . \mathrm{a}^{-1}\right)\end{array}$ \\
\hline 1 & 5O282B0002 & 15.48 & $-11.05 \pm 0.70$ & $-0.44 \pm 0.14$ & $-13.33 \pm 0.91$ & $-0.86 \pm 0.22$ & $-20.66 \pm 1.42$ & $-0.55 \pm 0.22$ \\
\hline 2 & 5O282B0004 & 13.63 & $-7.70 \pm 0.70$ & $-0.29 \pm 0.14$ & $-10.16 \pm 0.91$ & $-0.65 \pm 0.22$ & $-15.17 \pm 1.42$ & $-0.40 \pm 0.22$ \\
\hline 3 & $5 \mathrm{O} 282 \mathrm{~B} 0010$ & 4.99 & $-10.31 \pm 0.70$ & $-0.41 \pm 0.14$ & $-10.47 \pm 0.91$ & $-0.67 \pm 0.22$ & $-21.44 \pm 1.42$ & $-0.57 \pm 0.22$ \\
\hline 4 & $5 \mathrm{O} 282 \mathrm{~B} 0023$ & 7.46 & $-6.28 \pm 0.70$ & $-0.23 \pm 0.14$ & $-8.71 \pm 0.91$ & $-0.56 \pm 0.22$ & $-14.14 \pm 1.42$ & $-0.37 \pm 0.22$ \\
\hline 5 & $5 \mathrm{O} 282 \mathrm{~B} 0025$ & 26.72 & $-4.24 \pm 0.70$ & $-0.13 \pm 0.14$ & $-13.72 \pm 0.91$ & $-0.88 \pm 0.22$ & $-14.52 \pm 1.42$ & $-0.38 \pm 0.22$ \\
\hline 6 & $50282 B 0028$ & 98.99 & $-5.93 \pm 0.70$ & $-0.21 \pm 0.14$ & $-8.90 \pm 0.91$ & $-0.57 \pm 0.22$ & $-10.99 \pm 1.42$ & $-0.29 \pm 0.22$ \\
\hline 7 & 5O282B0037 & 193.45 & $-9.21 \pm 0.70$ & $-0.36 \pm 0.14$ & $-15.21 \pm 0.91$ & $-0.98 \pm 0.22$ & $-24.51 \pm 1.42$ & $-0.65 \pm 0.22$ \\
\hline \multicolumn{2}{|c|}{ 5O282B basin } & 471.06 & $-7.92 \pm 0.70$ & $-0.30 \pm 0.14$ & $11.85 \pm 0.91$ & $-0.76 \pm 0.22$ & $-19.13 \pm 1.42$ & $-0.51 \pm 0.22$ \\
\hline 8 & 5O291B0151 & 19.24 & $-8.47 \pm 0.80$ & $-0.33 \pm 0.16$ & $-7.66 \pm 0.16$ & $-0.49 \pm 0.04$ & $-18.56 \pm 0.72$ & $-0.49 \pm 0.11$ \\
\hline & 5O291B0196 & 56.60 & $-3.63 \pm 0.80$ & $-0.11 \pm 0.16$ & $-14.33 \pm 0.16$ & $-0.92 \pm 0.04$ & $-15.25 \pm 0.72$ & $-0.40 \pm 0.11$ \\
\hline & 5O291B0200 & 14.66 & $-2.93 \pm 0.80$ & $-0.08 \pm 0.16$ & $-10.49 \pm 0.16$ & $-0.67 \pm 0.04$ & $-14.16 \pm 0.72$ & $-0.37 \pm 0.11$ \\
\hline \multicolumn{2}{|c|}{ 5O291B basin } & 317.22 & $-4.14 \pm 0.80$ & $-0.13 \pm 0.16$ & $-9.74 \pm 0.16$ & $-0.63 \pm 0.04$ & $-14.77 \pm 0.72$ & $-0.39 \pm 0.11$ \\
\hline \multirow{4}{*}{\multicolumn{2}{|c|}{$\begin{array}{l}\text { Accumulation region } \\
\text { Ablation region } \\
\text { Debris-covered region } \\
\text { Clean-ice region }\end{array}$}} & 530.19 & $-4.95 \pm 0.77$ & $-0.22 \pm 0.16$ & $-5.69 \pm 0.43$ & $-0.37 \pm 0.10$ & $-12.06 \pm 0.54$ & $-0.32 \pm 0.08$ \\
\hline & & 258.09 & $-5.98 \pm 0.77$ & $-0.27 \pm 0.16$ & $-21.00 \pm 0.43$ & $-1.35 \pm 0.10$ & $-27.64 \pm 0.54$ & $-0.73 \pm 0.08$ \\
\hline & & 56.85 & $-8.87 \pm 0.77$ & $-0.40 \pm 0.16$ & $-27.39 \pm 0.43$ & $-1.76 \pm 0.10$ & $-33.50 \pm 0.54$ & $-0.89 \pm 0.08$ \\
\hline & & 731.43 & $-5.00 \pm 0.77$ & $-0.23 \pm 0.16$ & $-9.70 \pm 0.43$ & $-0.62 \pm 0.10$ & $-16.22 \pm 0.54$ & $-0.43 \pm 0.08$ \\
\hline \multicolumn{2}{|c|}{ Total } & 788.28 & $-5.30 \pm 0.77$ & $-0.24 \pm 0.16$ & $-11.04 \pm 0.43$ & $-0.71 \pm 0.10$ & $-17.46 \pm 0.54$ & $-0.46 \pm 0.08$ \\
\hline
\end{tabular}

Liu, 2000). Hence the assumption that any influence from the slight penetration of the X-band is negligible. The mean C-band penetration in the Kangri Karpo was 1.24 m, leading to average mass changes of +0.06 and $-0.08 \mathrm{mw}$ w.e. $^{-1}$ for 1980-2000 and 2000-2014.

Another issue relates to data voids in the accumulation area. Different assumptions, or elevation changes in the accumulation regions, were used to fill the data voids and to assess the impact on mass balance (Pieczonka et al., 2013; Shangguan et al., 2015). In this study, information on elevation change exists for all altitudinal zones from $2400 \mathrm{~m}$ to 6600 ma.s.l., but the area of data voids was too small to affect the mass balance significantly $(0.7 \%$ of the area above 6000 ma.s.1.), so it could be neglected.

\subsection{Changes in glacier area and length}

The ice cover in the Kangri Karpo was found to have diminished between 1980 and 2014 by about $0.71 \pm 0.06 \% \mathrm{a}^{-1}$. From 1980 to 2000 , glacier area decreased by $0.41 \pm$ $0.06 \% \mathrm{a}^{-1}$, increasing after 2000 to $0.52 \pm 0.10 \% \mathrm{a}^{-1}$. This result agrees with T. Yao et al. (2012), who found a shrinkage of $0.57 \% \mathrm{a}^{-1}$ in the south-eastern Tibetan Plateau from 1980 to 2001 . Their rate is slightly larger than ours, probably because of a difference in glacier size. In this and previous studies a greater relative loss has been measured for the smaller glaciers (Wei et al., 2014; Wu et al., 2016).

Compared with the retreat of mountain glaciers in western China, glaciers in the Kangri Karpo have experienced ex- tremely strong retreat rates. A rate of about $0.71 \% \mathrm{a}^{-1}$ is less than that in the Altai Mountains $\left(0.75 \% \mathrm{a}^{-1}\right)$ (X. Yao et al., 2012) but larger than that in other regions of western China, such as the Tian Shan $\left(0.22 \% \mathrm{a}^{-1}\right)$ (Wang et al., 2011), eastern Pamir $\left(0.25 \% \mathrm{a}^{-1}\right)$ (Zhang et al., 2016b), western Kunlun mountains $\left(0.09 \% \mathrm{a}^{-1}\right)$ (Bao et al., 2015), Qilian mountains $\left(0.47 \% \mathrm{a}^{-1}\right)$ (Sun et al., 2015) and the interior area of the Tibetan Plateau $\left(0.26 \% \mathrm{a}^{-1}\right)$ (Wei et al., 2014).

The location of glacier termini is often measured by remote sensing and field investigations. Due to the differences in the periods studied and spatial scales, the length changes of glacier centre lines in this study are less than in previous studies, except for the Azha Glacier (Liu et al., 2006; Yang et al., 2010; T. Yao et al., 2012). The snout of Parlung Glacier no. 10 was surveyed from 2006 to 2008 , but the survey period is too short to reflect changes over a longer time period (Yang et al., 2010). When comparing variations of Azha Glacier for different periods, $-56.1 \mathrm{ma}^{-1}$ from 1973 to 2005 (T. Yao et al., 2012), $-65 \mathrm{ma}^{-1}$ from 1980 to 2006 (Yang et al., 2010) and $-70 \mathrm{ma}^{-1}$ from 1980 to 2015 (this study), we found it had experienced greater retreat after the 2000s than before. Changes in the length of Yalong Glacier from 1980 to 2000 were similar to the $73 \mathrm{~m} \mathrm{a}^{-1}$ measured by Liu et al. (2006) between 1980 and 2001, after which the rate decreased significantly.

For advancing glaciers the mean size is about $0.51 \mathrm{~km}^{2}$, the mean surface slope is about $27.9^{\circ}$, mostly with a $S$ or SW aspect, and the mean accumulation area ratio (AAR) is 51. Previous studies also found advancing glaciers in the 

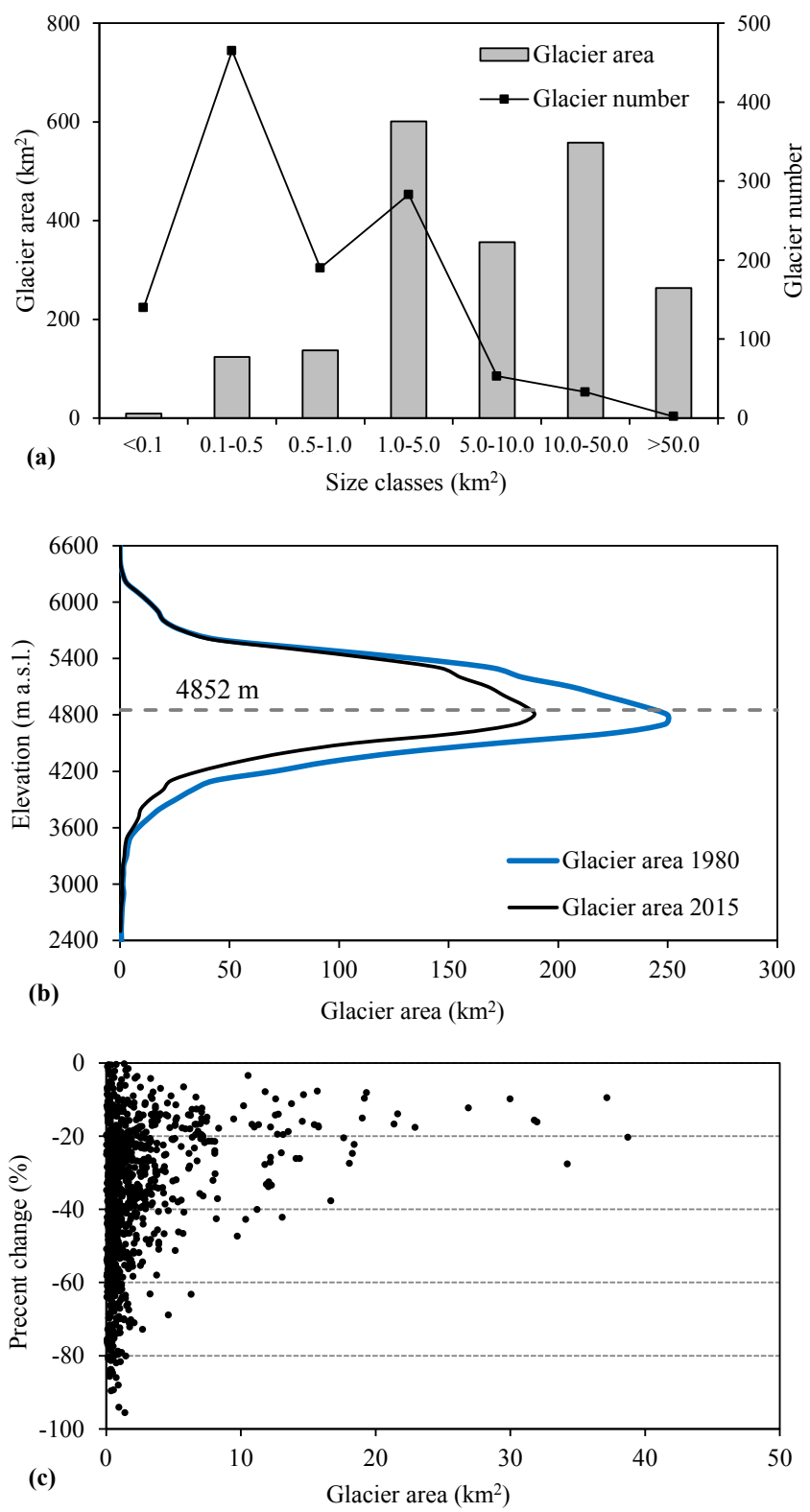

Figure 5. Glacier distribution and change in the Kangri Karpo. (a) Number and area of glaciers in different size categories. (b) Hypsography of glaciers in 1980 and 2015; the dashed line depicts the median elevation value. (c) Percentage change in glacier area from 1980 to 2015 .

Kangri Karpo (Liu et al., 2006; Shi et al., 2006). Comparison of the CGI2 and GAMDAM inventories shows that the locations of most glacier termini in 2000 are very close to those in 2014, indicating that the advance mainly occurred before 2000 . Unfortunately, due to location and climatic features, most Landsat MSS/TM image quality was too low to identify the snouts. Fortunately, two Landsat TM scenes (LT51340401994189BKT00 and LT51340401988301BJC00) had a high enough quality to be
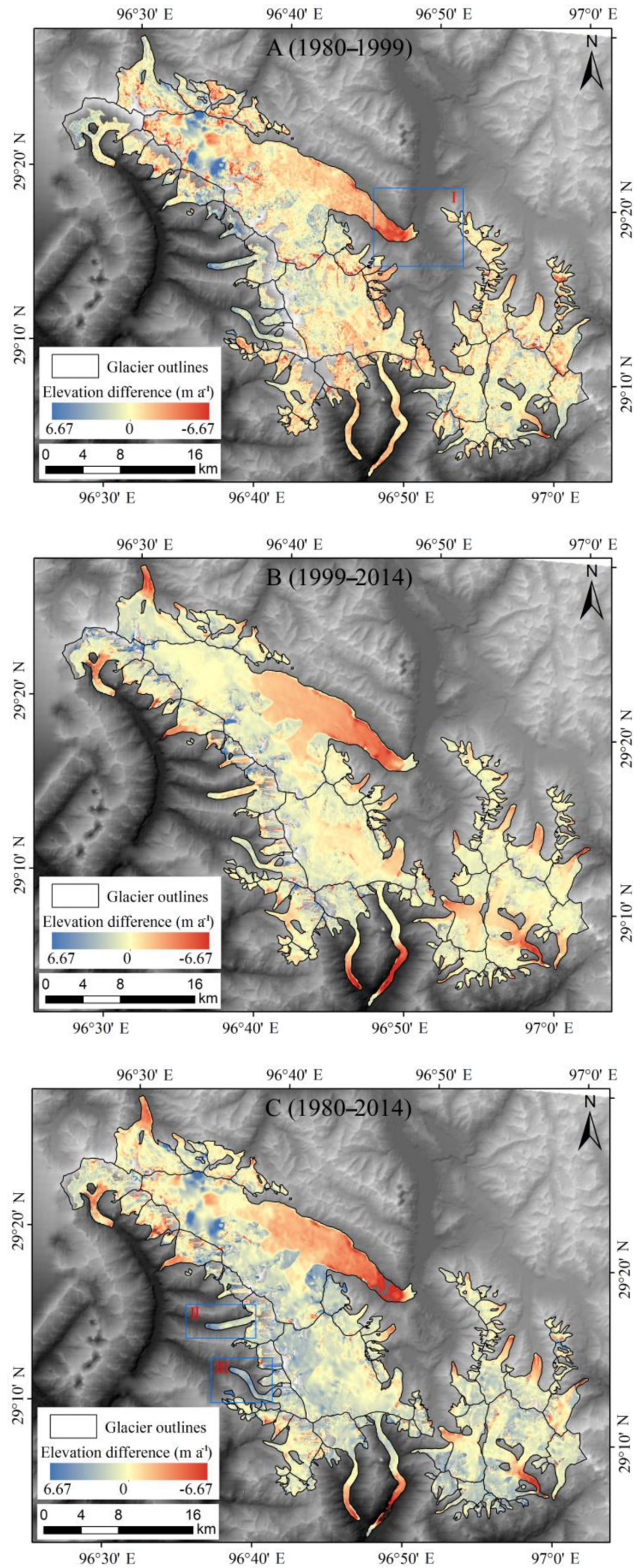

Figure 6. Elevation changes in the Kangri Karpo from 1980 to 2014. The glacier outlines are based on the geometric union of the 1980,2000 s and 2015 glacier extent. II and III are two glaciers with positive elevation changes in their tongues. 
used. When comparing the Landsat image of the terminus of Glacier 5O282B0111 (Fig. 3b), it could be determined that the advance occurred mainly before 1988, after which time the glacier retreated continuously (Fig. 7), and was likely due to increased precipitation in the 1980s (Shi et al., 2006). Annual precipitation data for 1980-2012 from the three nearest meteorological stations (Bomê, Zuogong and Zayü) indicated that the maximum precipitation was 1.3 times the mean precipitation over these decades $(1153 \mathrm{~mm}$ in 1988 vs. $891 \mathrm{~mm})$ at Bomê $\left(29^{\circ} 52^{\prime} \mathrm{N}, 9^{\circ} 46^{\prime} \mathrm{E}, 2736 \mathrm{~m}\right.$ a.s.1.). At Zuogong $\left(29^{\circ} 40^{\prime} \mathrm{N}, 97^{\circ} 50^{\prime} \mathrm{E}, 3780 \mathrm{ma}\right.$ a.s.1.) the maximum precipitation was 1.5 times the mean $(683 \mathrm{~mm}$ in 1987 vs. $405 \mathrm{~mm})$, while at Zayü $\left(28^{\circ} 39^{\prime} \mathrm{N}, 97^{\circ} 28^{\prime} \mathrm{E}, 2423 \mathrm{~m}\right.$ a.s.1.) it was 1.4 times the mean (1091 mm in 1988 vs. $792 \mathrm{~mm})$. Assuming that variations in precipitation at the high-elevation glacier areas reflect those of the three nearest meteorological stations, the increased accumulation could certainly have influenced terminus activity. In complex terrain the accumulation distribution varies greatly so the response of glaciers may differ: some individual glaciers did advance between 1980 and 1988.

\subsection{Glacier thinning and mass balance}

A comparison of glacier thickness changes showed significant differences in the eastern Nyainqentanglha mountains. Using SRTM and SPOT5 DEMs (24 November 2011), glaciers experienced a mean thinning of $0.39 \pm 0.16 \mathrm{ma}^{-1}$ (Gardelle et al., 2013). Based on ICESat and SRTM, Kääb et al. (2015), Neckel et al. (2014) and Gardner et al. (2013) acquired different results over the Kangri Karpo, with glacier thickness losses of $1.34 \pm 0.29,0.81 \pm 0.32$ and $0.30 \pm$ $0.13 \mathrm{ma}^{-1}$ during 2003-2009 respectively. Using SRTM DEM and TerraSAR-X/TanDEM-X acquisitions (18 February 2014 and 13 March 2014), glaciers were shown to have experienced a mean thinning of $0.79 \pm 0.11 \mathrm{ma}^{-1}$ in the Kangri Karpo. At a first glance, this result agrees with Neckel et al. (2014) but has significant differences from Kääb et al. (2015). The main reason for this discrepancy is the different estimation of SRTM C-band penetration. An average SRTM C-band penetration of $1.24 \mathrm{~m}$ was used for the Kangri Karpo, estimated from the difference in SRTM C- and X-band DEMs (Gardelle et al., 2012a). Kääb et al. (2015) employed an average penetration of $8-10 \mathrm{~m}$ for the eastern Nyainqentanglha mountains but $7-9 \mathrm{~m}$ if based on winter trends that might alternatively be assumed to reflect February conditions. Previous studies had indicated that penetration depth varies with temperature and water content (Surdyk, 2002) and penetrations of the SRTM C-band from 1.4 to $3.4 \mathrm{~m}$ were estimated for the Pamir-Karakoram-Himalaya (Gardelle et al., 2013; Kääb et al., 2012). As the characteristics of glaciers in the eastern Nyainqentanglha mountains are similar to those in the eastern Himalaya (Shi et al., 2008b), it is appropriate to assume the penetrations are too.

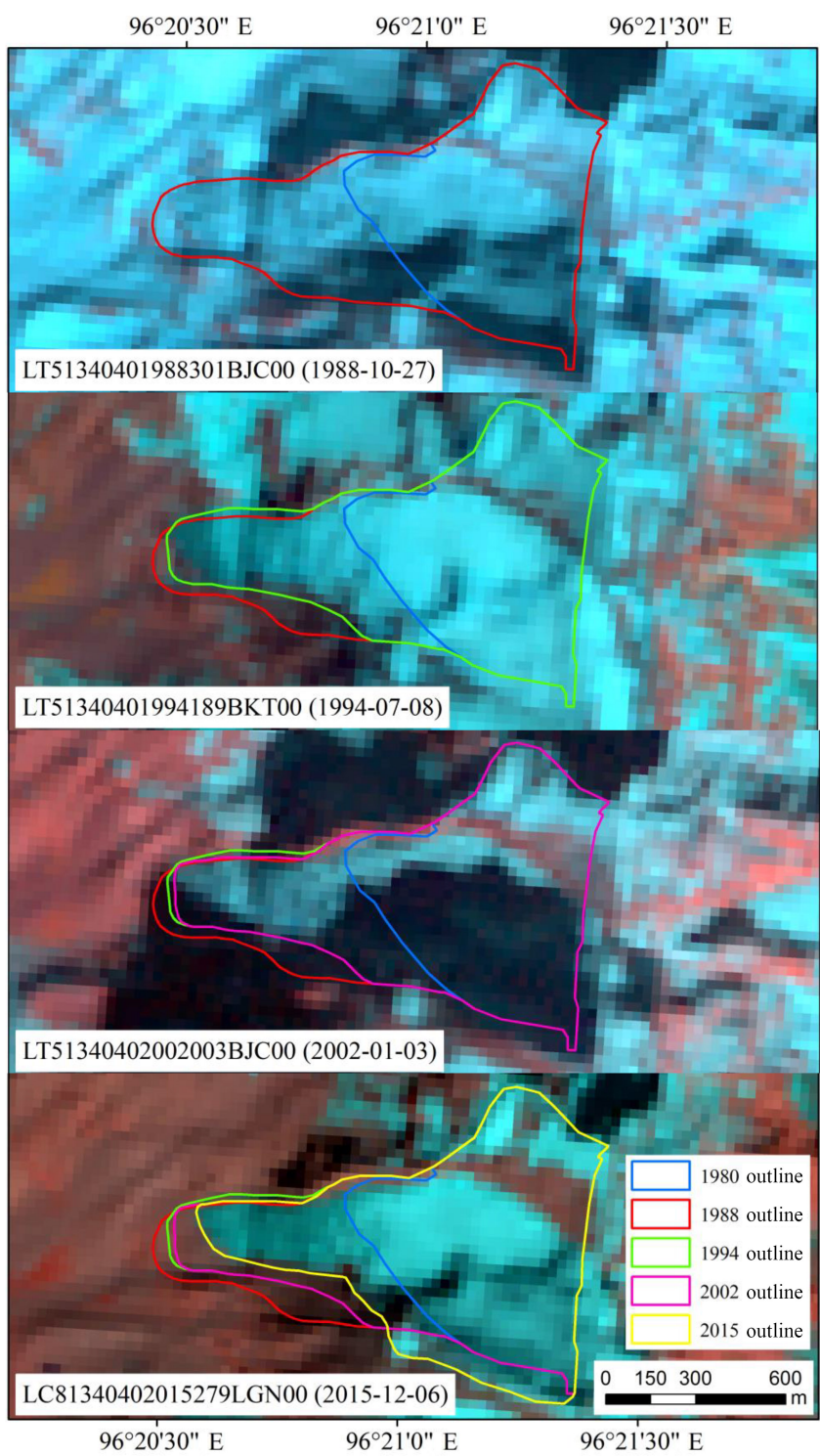

Figure 7. Terminus changes of Glacier 5O282B0111 from 1980 to 2015. Location of the data example is shown in Fig. 3 b.

Field measurement of mass balance is the best indicator of glacier change. A monitoring programme has been carried out on Parlung Glacier no. 4 (5O282B0004/G096920E29228N) and Parlung Glacier no. 10 (5O282B0010/G096904E29286N), both of which are on the northern slope of the Kangri Karpo. Large ice deficits were found on them at rates of $-0.71 \mathrm{mw} . e . \mathrm{a}^{-1}$ from May 2006 to May 2007 and $-0.78 \mathrm{mw} . e . \mathrm{a}^{-1}$ for 2005-2009 respectively (Yang et al., 2008; T. Yao et al., 2012). Based on SRTM DEM and TerraSAR-X/TanDEM-X acquisitions (18 February 2014), the two glaciers experienced substantial downwasting from 2000 to 2014, with mean mass deficits of $0.65 \pm 0.22$ and $0.67 \pm 0.22 \mathrm{mw}$.e. $\mathrm{a}^{-1}$. The comparison between field measurements and remote 

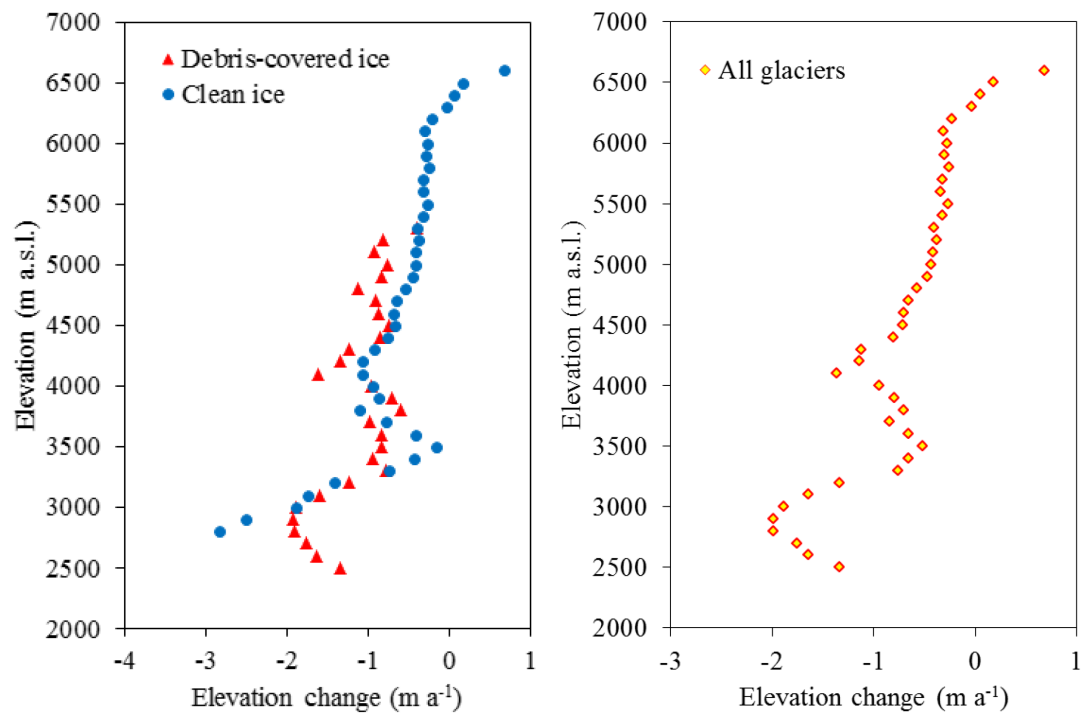

Figure 8. Glacier elevation changes at each $100 \mathrm{~m}$ interval by altitude in the Kangri Karpo for clean ice, debris-covered ice and all glaciers for the period 1980-2014.

sensing showed a high consistency in the mass deficits for the Parlung glaciers nos. 4 and 10.

Thinning was noticeably greater on the glacier debris cover than on the white ice in the $2800-5300$ ma.s.l. altitude range from 1980 to $2014\left(-0.99 \pm 0.09 \mathrm{ma}^{-1}\right.$ vs. $-0.89 \pm 0.08 \mathrm{~m}$ w.e. $\mathrm{a}^{-1}$ ) (Fig. 8). Clean ice extended down to 2800 ma.s.l., whereas 5300 ma.s.l. was the highest altitude of the debris-covered region. The mass-loss patterns on a debris-covered tongue are complex, with supraglacial lakes, ice cliffs and a heterogeneous debris cover, (Pellicciotti et al., 2015). Although it is generally believed that ablation rates are retarded with a thick debris cover due to its insulation effect, some previous studies have found that ablation is greater when the debris is less than a critical thickness (Nakawo and Young, 1981; Pu et al., 2003; Ye et al., 2015; Zhang et al., 2011, 2016a). The debris-covered regions at lower altitudes with higher temperatures and the development of supraglacial lakes and ice cliffs likely contributed to the larger mass loss in those regions (Benn et al., 2012; Sakai and Fujita, 2010).

Overall, negative elevation changes were found for all glaciers except two on the southern slope of the Kangri Karpo (Fig. 6c). When comparing the average changes of these two tongues from 1980 to 2000 and 2000 to 2014, positive changes were found between October 1980 and February 2000 , and negative changes after 2000 . Unfortunately, the situation in the accumulation areas of these glaciers is unknown due to data voids. This activity might be interpreted as the result of higher precipitation (Shi et al., 2006).

\subsection{Climatic considerations}

The Kangri Karpo climate is characterized by westerly winds in winter and the Indian monsoon in summer (Li et al., 1986). The former are weak due to blocking by the Tibetan Plateau. Thus, accumulation on the glaciers comes mainly from the summer monsoon (Bolch et al., 2010a; T. Yao et al., 2012). Previous studies have indicated that the Tibetan Plateau has experienced an overall warming since the mid-1950s (Duan et al., 2015; Li et al., 2010; Liu et al., 2008, 2009; Qin et al., 2009; Yang et al., 2014; T. Yao et al., 2012; You et al., 2010). The trend is slightly different in the south-eastern TP. Local meteorological station data show the south-eastern TP as having the lowest warming rate (Duan et al., 2015), yet the MODIS land surface temperature (MODIS LST) showed a higher rate (Yang et al., 2014), while a decreasing trend of average annual temperature came from the National Centers for Environmental Prediction/National Center for Atmospheric Research (NCEP/NCAR) reanalysis data (You et al., 2010). Changes in air temperature are accompanied by changes in precipitation due to variations in monsoonal activity. The Global Precipitation Climatology Project (GPCP) data show precipitation decreasing in the south-eastern TP from 1979 to 2010 (T. Yao et al., 2012). Annual precipitation from Chinese meteorological station data for the southeastern TP exhibit a positive trend, precipitation amounts have increased and the frequency of severely dry events decreased significantly ( $\mathrm{Li}$ et al., 2010). The ambiguous nature of these results means the glacier and mass balance changes presented cannot be explained directly by the summarized information on climate change.

To analyse the response of the Kangri Karpo glaciers to climate change, relevant air temperature and precipitation 
data sets were taken from the China Meteorological Forcing Data set (CMFD, 1 January 1979-31 December 2012) (Chen et al., 2011; He and Yang, 2011). The CFMD has been produced by merging a variety of data sources, including meteorological station data, TRMM satellite precipitation analysis data, GEWEX-SRB downward shortwave radiation data and GLDAS data (http://westdc.westgis.ac.cn/data/ 7a35329c-c53f-4267-aa07-e0037d913a21). The horizontal distributions of surface temperature and precipitation change from May to September derived from this data are shown in Fig. 9. It is clear that warming has been a dominant phenomenon in the south-eastern TP during recent decades. The warming rate on the northern slope of the Kangri Karpo is slightly larger than on the southern slope. The evidence of precipitation change was inconsistent in that an increasing trend was present in much of the Kangri Karpo, yet there was a decreasing trend in the eastern part of the range. The changes in air temperature and precipitation were confirmed with data from the three nearest meteorological stations, Bomê, Zuogong and Zayü (2423 ma.s.1.) (Liu et al., 2006; Yang et al., 2010). Air temperature at these stations increased slightly from 1980 to 2000 and then significantly after 2000. Despite large interannual precipitation fluctuations statistically significant trends are not evident at the three stations (Wu et al., 2016a; Yang et al., 2010).

Rainfall increased slightly in the Kangri Karpo during 1980-2012. This increase in precipitation resulted in more glacier accumulation, yet the glaciers experienced an intense mass deficit. Other factors must be playing a more important role in this deficit. In the case of temperature, warming was present in the Kangri Karpo during 1980-2012. Meteorological station records indicate that average air temperature increased in the Kangri Karpo Mountains by more than $0.2^{\circ} \mathrm{C}$ per decade (with confidence level $<0.05$ ), higher than the global rate of warming $\left(0.12^{\circ} \mathrm{C}\right.$ per decade, $\left.1951-2012\right)$. The rate of warming on the northern slope is slightly larger than on the southern slope. Meteorological station records showed that average air temperature increased at 0.27 and $0.25^{\circ} \mathrm{C}$ per decade at the Bomê and Zuogong stations, slightly higher than at Zayü station $\left(0.2^{\circ} \mathrm{C}\right.$ per decade). While a small warming rate was present from 1980 to 2000, it increased to large warming rate thereafter. This is consistent with how the glaciers have changed. In the Kangri Karpo they have experienced a substantial area reduction and mass deficit. The mean mass deficit in the drainage basin 5O282B (on the northern slope) was larger than in drainage basin 5O291B (on the southern slope) during 1980-2014. Furthermore, the rate of glacier shrinkage and mass loss from 1980 to 2000 was less than from 2000 to 2015. Thus, the changes leading to glacier wastage in the Kangri Karpo can be attributed to climate warming.
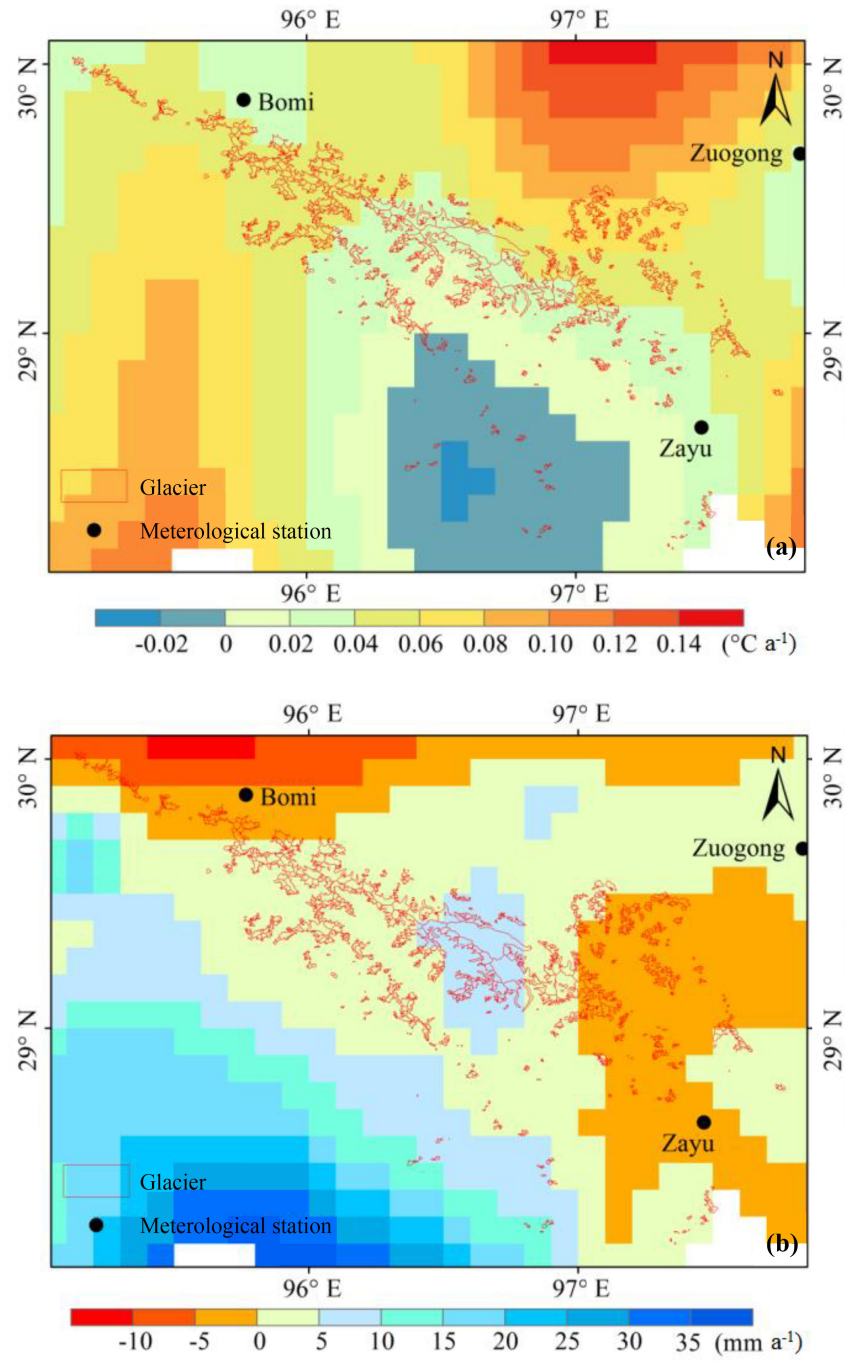

Figure 9. The changes of temperature and precipitation (from May to September) in the Kangri Karpo during 1979-2012. (a) Temperature, (b) precipitation.

\section{Conclusions}

This study estimated area, length, surface elevation and mass balance of the Kangri Karpo glaciers for the period 19802015 based on topographic maps, Landsat images, SRTM and TerraSAR-X/TanDEM-X acquisitions.

Results show that the Kangri Karpo contained 1166 glaciers with an area of $2048.50 \pm 48.65 \mathrm{~km}^{2}$ in 2015 . Ice cover diminished by $679.51 \pm 59.49 \mathrm{~km}^{2}(24.9 \pm 2.2 \%)$ or $0.71 \pm 0.06 \% \mathrm{a}^{-1}$ from 1980 to 2015 . When comparing the termini of all glaciers, only nine glaciers showed advance while the others retreated. Compared with the recession of mountain glaciers in western China, glaciers in the Kangri Karpo have experienced extremely strong retreat.

The average elevation change of the entire glacier surface in the Kangri Karpo study area was $-0.51 \pm 0.09 \mathrm{ma}^{-1}$, 
indicating a mean mass deficit of $0.46 \pm 0.08 \mathrm{mw} . e . \mathrm{a}^{-1}$ from 1980 to 2014. The mass balance over this period was heterogeneous. Comparisons between field measurements of mass balance and the results of this study indicate a high consistency between the glacier mass losses of Parlung Glacier no. 4 and Parlung Glacier no. 10. Geodetic mass-balance measurements showed that the debris-covered regions had, on average, higher thinning rates than the clean-ice regions, averaging $-0.99 \pm 0.09 \mathrm{ma}^{-1}(-0.89 \pm$ $0.08 \mathrm{mw}$ e. $\mathrm{a}^{-1}$ ) from 1980 to 2014 . The rates of glacier shrinkage and mass loss from 1980 to 2000 were slightly lower than those from 2000 to 2015.

Data availability. Landsat images are from the US Geological Survey and NASA. The GAMDAM glacier inventory was provided by A. Sakai. The first and second glacier inventories were provided by a recent MOST project (2006FY110200) (https://doi.org/10.3972/glacier.001.2013.db; Liu et al., 2014). The China Meteorological Forcing Data set (CMFD) is from the Cold and Arid Regions Science Data Center in Lanzhou (https://doi.org/10.3972/westdc.002.2014.db; He and Yang, 2011).

Competing interests. The authors declare that they have no conflict of interest.

Acknowledgements. This work was supported by the fundamental programme of the Ministry of Science and Technology of China (MOST) (grant no. 2013FY111400), the National Natural Science Foundation of China (grant no. 41190084), the International Partnership Programme of the Chinese Academy of Sciences (grant no. 131C11KYSB20160061) and the grant for talent introduction of Yunnan University. Landsat images are from the US Geological Survey and NASA. The GAMDAM glacier inventory was provided by A. Sakai. The first and second glacier inventories were provided by a recent MOST project (2006FY110200). The China Meteorological Forcing Data set (CMFD) is from the Cold and Arid Regions Science Data Center in Lanzhou. All SAR processing was done with GAMMA SAR and interferometric processing software. We thank DLR for free access to SRTM Xband data and USGS for free access to SRTM C-band and Landsat data. ASTER GDEM and SRTM are a product of METI and NASA.

Edited by: Benjamin Smith

Reviewed by: two anonymous referees

\section{References}

Arendt, A., Bliss, A., Bolch, T., Cogley, J. G., and Gardner, A. S.: Randolph glacier inventory - a dataset of global glacier outlines. Version 5.0, University of Colorado. National Snow and Ice Data Center (NSIDC). Global Land Ice Measurements from Space (GLIMS), Boulder, CO, digital media, available at: www.glims. org/RGI/00_rgi50_TechnicalNote.pdf (last access: 12 March 2017), 2015.
Bao, W.-J., Liu, S.-Y., Wei, J.-F., and Guo, W.-Q.: Glacier changes during the past 40 years in the West Kunlun Shan, J. Mt. Sci., 12, 344-357, https://doi.org/10.1007/s11629-014-3220-0, 2015.

Benn, D. I., Bolch, T., Hands, K., Gulley, J., Luckman, A., Nicholson, L. I., Quincey, D., Thompson, S., Toumi, R., and Wiseman, S.: Response of debris-covered glaciers in the Mount Everest region to recent warming, and implications for outburst flood hazards, Earth-Sci. Rev., 114, 156-174, https://doi.org/10.1016/j.earscirev.2012.03.008, 2012.

Berthier, E., Arnaud, Y., Vincent, C., and Rémy, F.: Biases of SRTM in high-mountain areas: implications for the monitoring of glacier volume changes, Geophys. Res. Lett., 33, L08502, https://doi.org/10.1029/2006GL025862, 2006.

Berthier, E., Schiefer, E., Clarke, G. K. C., Menounos, B., and Rémy, F.: Contribution of Alaskan glaciers to sea-level rise derived from satellite imagery, Nat. Geosci., 3, 92-95, https://doi.org/10.1038/ngeo737, 2010.

Bolch, T., Menounos, B., and Wheate, R.: Landsat-based inventory of glaciers in western Canada, 1985-2005, Remote Sens. Environ., 114, 127-137, https://doi.org/10.1016/j.rse.2009.08.015, 2010a.

Bolch, T., Yao, T., Kang, S., Buchroithner, M. F., Scherer, D., Maussion, F., Huintjes, E., and Schneider, C.: A glacier inventory for the western Nyainqentanglha Range and the Nam Co Basin, Tibet, and glacier changes 1976-2009, The Cryosphere, 4, 419433, https://doi.org/10.5194/tc-4-419-2010, 2010b.

Bolch, T., Pieczonka, T., and Benn, D. I.: Multi-decadal mass loss of glaciers in the Everest area (Nepal Himalaya) derived from stereo imagery, The Cryosphere, 5, 349-358, https://doi.org/10.5194/tc-5-349-2011, 2011.

Chen, Y., Yang, K., He, J., Qin, J., Shi, J., Du, J., and He, Q.: Improving land surface temperature modeling for dry land of China, J. Geophys. Res., 116, D20104, https://doi.org/10.1029/2011JD015921, 2011.

Chinese National Standard: Compilation specifications for national fundamental scale maps. Part 1: Compilation soecifications for $1: 25000 / 1: 50000 / 1: 100000$ topographic maps, GB/T 12343.1-2008, General Administration of Quality Supervision, Inspection and Quarantine, Beijing, China, 2008.

Dall, J., Madsen, S. N., Keller, K., and Forsberg, R.: Topography and penetration of the Greenland ice sheet measured with airborne SAR interferometry, Geophys. Res. Lett., 28, 1703-1706, https://doi.org/10.1029/2000GL011787, 2001.

Davis, C. H. and Poznyak, V. I.: The depth of penetration in Antarctic firn at $10 \mathrm{GHz}$, IEEE T. Geosci. Remote, 31, 1107-1111, https://doi.org/10.1109/36.263784, 1993.

Duan, J., Li, L., and Fang, Y.: Seasonal spatial heterogeneity of warming rates on the Tibetan Plateau over the past 30 years, Sci. Rep.-UK, 5, 11725, https://doi.org/10.1038/srep11725, 2015.

Farr, T. G., Rosen, P. A., Caro, E., Crippen, R., Duren, R., Hensley, S., Kobrick, M., Paller, M., Rodriguez, E., Roth, L., Seal, D., Shaffer, S., Shimada, J., Umland, J., Werner, M., Oskin, M., Burbank, D., and Alsdorf, D.: The Shuttle Radar Topography Mission, Rev. Geophys., 45, RG2004, https://doi.org/10.1029/2005RG000183, 2007.

Gardelle, J., Berthier, E., and Arnaud, Y.: Impact of resolution and radar penetration on glacier elevation changes computed from DEM differencing, J. Glaciol., 58, 419-422, https://doi.org/10.3189/2012JoG11J175, 2012a. 
Gardelle, J., Berthier, E., and Arnaud, Y.: Slight mass gain of Karakoram glaciers in the early twenty-first century, Nat. Geosci., 5, 322-325, https://doi.org/10.1038/ngeo1450, 2012b.

Gardelle, J., Berthier, E., Arnaud, Y., and Kääb, A.: Regionwide glacier mass balances over the Pamir-KarakoramHimalaya during 1999-2011, The Cryosphere, 7, 1263-1286, https://doi.org/10.5194/tc-7-1263-2013, 2013.

Gardner, A. S., Moholdt, G., Cogley, J. G., Wouters, B., Arendt, A. A., Wahr, J., Berthier, E., Hock, R., Pfeffer, W. T., Kaser, G., Ligtenberg, S. R. M., Bolch, T., Sharp, M. J., Hagen, J. O., van den Broeke, M. R., and Paul, F.: A reconciled estimate of glacier contributions to sea level rise: 2003 to 2009 , Science, 340, 852-857, https://doi.org/10.1126/science.1234532, 2013.

Goldstein, R. M. and Werner, C. L.: Radar interferogram filtering for geophysical applications, Geophys. Res. Lett., 25, 40354038, https://doi.org/10.1029/1998GL900033, 1998.

Guo, W., Liu, S., Yu, P., and Xu, J.: Automatic extraction of ridgelines using on drainage boundaries and aspect difference, Sci. Surv. Map., 36, 210-213, 2011.

Guo, W., Liu, S., Xu, J., Wu, L., Shangguan, D., Yao, X., Wei, J., Bao, W., Yu, P., Liu, Q., and Jiang, Z.: The second Chinese glacier inventory: data, methods, and results, J. Glaciol., 61, 357372, https://doi.org/10.3189/2015JoG14J209, 2015.

He, J. and Yang, K.: China meteorological forcing dataset, Cold and Arid Regions Science Data Center, Lanzhou, China, digital media, https://doi.org/10.3972/westdc.002.2014.db, 2011.

Immerzeel, W. W., van Beek, L. P. H., and Bierkens, M. F. P.: Climate change will affect the Asian water towers, Science, 328, 1382-1385, https://doi.org/10.1126/science.1183188, 2010.

IPCC: Summary for policymakers, in: Climate change 2013: The physical science basis. Contribution of Working Group I to the Fifth Assessment Report of the Intergovernmental Panel on Climate Change, edited by: Stocker, T. F., Qin, D., Plattner, G. K., Tignor, M., Allen, S. K., Boschung, J., Nauels, A., Xia, Y., Bex, V., and Midgley, P. M., Cambridge University Press, Cambridge, UK and New York, NY, USA, 1-30, https://doi.org/10.1017/CBO9781107415324.004, 2013.

Kääb, A., Berthier, E., Nuth, C., Gardelle, J., and Arnaud, Y.: Contrasting patterns of early twenty-first-century glacier mass change in the Himalayas, Nature, 488, 495-498, https://doi.org/10.1038/nature11324, 2012.

Kääb, A., Treichler, D., Nuth, C., and Berthier, E.: Brief Communication: Contending estimates of 2003-2008 glacier mass balance over the Pamir-Karakoram-Himalaya, The Cryosphere, 9, 557564, https://doi.org/10.5194/tc-9-557-2015, 2015.

Kienholz, C., Rich, J. L., Arendt, A. A., and Hock, R.: A new method for deriving glacier centerlines applied to glaciers in Alaska and northwest Canada, The Cryosphere, 8, 503-519, https://doi.org/10.5194/tc-8-503-2014, 2014.

Koblet, T., Gärtner-Roer, I., Zemp, M., Jansson, P., Thee, P., Haeberli, W., and Holmlund, P.: Reanalysis of multi-temporal aerial images of Storglaciären, Sweden (1959-99) - Part 1: Determination of length, area, and volume changes, The Cryosphere, 4 , 333-343, https://doi.org/10.5194/tc-4-333-2010, 2010.

Krieger, G., Moreira, A., Fiedler, H., Hajnsek, I., Werner, M., Younis, M., and Zink, M.: TanDEM-X: A satellite formation for high-resolution SAR interferometry, IEEE T. Geosci. Remote,
45, 3317-3341, https://doi.org/10.1109/TGRS.2007.900693, 2007.

Le Bris, R. and Paul, F.: An automatic method to create flow lines for determination of glacier length: a pilot study with Alaskan glaciers, Comput. Geosci., 52, 234-245, https://doi.org/10.1016/j.cageo.2012.10.014, 2013.

Leclercq, P. W., Oerlemans, J., Basagic, H. J., Bushueva, I., Cook, A. J., and Le Bris, R.: A data set of worldwide glacier length fluctuations, The Cryosphere, 8, 659-672, https://doi.org/10.5194/tc-8-659-2014, 2014.

Li, J., Zheng, B., and Yang, X.: The Glaciers of Xizang (Tibet), Scientific Expedition to the Qinghai-Xizang Plateau, Science Press, Chinese Academy of Sciences, Beijing, 1986.

Li, X., Cheng, G., Jin, H., Kang, E., Che, T., Jin, R., Wu, L., Nan, Z., Wang, J., and Shen, Y.: Cryospheric change in China, Global Planet. Change, 62, 210-218, https://doi.org/10.1016/j.gloplacha.2008.02.001, 2008.

Li, L., Yang, S., Wang, Z., Zhu, X., and Tang, H.: Evidence of warming and wetting climate over the QinghaiTibet Plateau, Arct. Antarct. Alp. Res., 42, 449-457, https://doi.org/10.1657/1938-4246-42.4.449, 2010.

Li, X., Yang, T.-B., and Ji, Q.: Study on glacier variations in the Gangrigabu Range, Res. Soil Water Conserv., 21, 233-237, https://doi.org/10.13869/j.cnki.rswc.2014.04.046, 2014.

Liu, S., Shangguan, D., Ding, Y., Han, H., Xie, C., Zhang, Y., Li, J., Wang, J., and Li, G.: Glacier changes during the past century in the Gangrigabu mountains, southeast Qinghai-Xizang (Tibetan) Plateau, China, Adv. Clim. Change Res., 43, 187-193, https://doi.org/10.3189/172756406781812348, 2006.

Liu, S., Guo, W., Xu, J., Shangguan, D., Wu, L., Yao, X., Zhao, J., Liu, Q., Jiang, Z., Li, P., Wei, J., Bao, W., Yu, P., Ding, L., Li, G., Ge, C., and Wang, Y.: The Second Glacier Inventory Dataset of China (Version 1.0). Cold and Arid Regions Science Data Center at Lanzhou, https://doi.org/10.3972/glacier.001.2013.db, 2014.

Liu, W., Guo, Q., and Wang, Y.: Temporal-spatial climate change in the last 35 years in Tibet and its geo-environmental consequences, Environ. Geol. Berlin, 54, 1747-1754, https://doi.org/10.1007/s00254-007-0952-y, 2008.

Liu, X., Cheng, Z., Yan, L., and Yin, Z.-Y.: Elevation dependency of recent and future minimum surface air temperature trends in the Tibetan Plateau and its surroundings, Global Planet. Change, 68, 164-174, https://doi.org/10.1016/j.gloplacha.2009.04.001, 2009.

Mi, D., Xie, Z., Luo, X., Feng, Q., Ma, M., and Jin, D.: Glacier inventory of China XI. the Ganga drainage basin. XII. Indus drainage basin, Xi'an Cartographic Publishing House, Lanzhou Institute of Glaciology and Geocryology, Xi'an, 2002.

Nakawo, M. and Young, G. J.: Field experiments to determine the effect of a debris layer on ablation of glacier ice, Ann. Glaciol., 2, 85-91, https://doi.org/10.3189/172756481794352432, 1981.

Neckel, N., Braun, A., Kropáček, J., and Hochschild, V.: Recent mass balance of the Purogangri Ice Cap, central Tibetan Plateau, by means of differential X-band SAR interferometry, The Cryosphere, 7, 1623-1633, https://doi.org/10.5194/tc-71623-2013, 2013.

Neckel, N., Kropáček, J., Bolch, T., and Hochschild, V.: Glacier mass changes on the Tibetan Plateau 2003-2009 derived from ICESat laser altimetry measurements, Environ. Res. Lett., 9, 014009, https://doi.org/10.1088/1748-9326/9/1/014009, 2014. 
Nuimura, T., Sakai, A., Taniguchi, K., Nagai, H., Lamsal, D., Tsutaki, S., Kozawa, A., Hoshina, Y., Takenaka, S., Omiya, S., Tsunematsu, K., Tshering, P., and Fujita, K.: The GAMDAM glacier inventory: a quality-controlled inventory of Asian glaciers, The Cryosphere, 9, 849-864, https://doi.org/10.5194/tc9-849-2015, 2015.

Nuth, C. and Kääb, A.: Co-registration and bias corrections of satellite elevation data sets for quantifying glacier thickness change, The Cryosphere, 5, 271-290, https://doi.org/10.5194/tc-5-2712011, 2011.

Oerlemans, J.: Quantifying global warming from the retreat of glaciers, Science, 264, 243-245, https://doi.org/10.1126/science.264.5156.243, 1994.

Paul, F. and Haeberli, W.: Spatial variability of glacier elevation changes in the Swiss Alps obtained from two digital elevation models, Geophys. Res. Lett., 35, L21502, https://doi.org/10.1029/2008GL034718, 2008.

Paul, F. and Svoboda, F.: A new glacier inventory on southern Baffin Island, Canada, from ASTER data: II. Data analysis, glacier change and applications, Ann. Glaciol., 50, 22-31, https://doi.org/10.3189/172756410790595921, 2009.

Paul, F., Huggel, C., Kääb, A., Kellenberger, T., and Maisch, M.: Comparison of TM-derived glacier areas with higher resolution data sets, EARSeL eProc., 2, 15-21, available at: www.eproceedings.org/static/vol02_1/02_1_paul1.pdf (last access: 6 February 2017), 2003.

Paul, F., Barry, R. G., Cogley, J. G., Frey, H., Haeberli, W., Ohmura, A., Ommanney, C. S. L., Raup, B., Rivera, A., and Zemp, M.: Recommendations for the compilation of glacier inventory data from digital sources, Ann. Glaciol., 50, 119-126, https://doi.org/10.3189/172756410790595778, 2009.

Paul, F., Barrand, N. E., Baumann, S., Berthier, E., Bolch, T., Casey, K., Frey, H., Joshi, S. P., Konovalov, V., Le Bris, R., Mölg, N., Nosenko, G., Nuth, C., Pope, A., Racoviteanu, A., Rastner, P., Raup, B., Scharrer, K., Steffen, S., and Winsvold, S.: On the accuracy of glacier outlines derived from remote-sensing data, Ann. Glaciol., 54, 171-182, https://doi.org/10.3189/2013AoG63A296, 2013.

Pellicciotti, F., Stephan, C., Miles, E., Herreid, S., Immerzeel, W. W., and Bolch, T.: Mass-balance changes of the debris-covered glaciers in the Langtang Himal, Nepal, between 1974 and 1999, J. Glaciol., 61, 373-386, https://doi.org/10.3189/2015JoG13J237, 2015.

Pfeffer, W. T., Arendt, A. A., Bliss, A., Bolch, T., Cogley, J. G., Gardner, A. S., Hagen, J.-O., Hock, R., Kaser, G., Kienholz, C., Miles, E. S., Moholdt, G., Mölg, N., Paul, F., Radić, V., Rastner, P., Raup, B. H., Rich, J., Sharp, M. J., and the Randolph Consortium: The Randolph Glacier Inventory: a globally complete inventory of glaciers, J. Glaciol., 60, 537-552, https://doi.org/10.3189/2014JoG13J176, 2014.

Pieczonka, T., Bolch, T., Wei, J., and Liu, S.: Heterogeneous mass loss of glaciers in the Aksu-Tarim catchment (central Tien Shan) revealed by 1976 KH-9 Hexagon and 2009 SPOT-5 stereo imagery, Remote Sens. Environ., 130, 233-244, https://doi.org/10.1016/j.rse.2012.11.020, 2013.

$\mathrm{Pu}$, J., Yao, T., and Duan, K.: An observation on surface ablation on the Yangbark glacier in the Muztagata Ata, China, J. Glaciol. Geocryol., 25, 680-684, 2003.
Qin, J., Yang, K., Liang, S., and Guo, X.: The altitudinal dependence of recent rapid warming over the Tibetan Plateau, Climatic Change, 97, 321-327, https://doi.org/10.1007/s10584-009-97339, 2009.

Rabus, B., Eineder, M., Roth, A., and Bamler, R.: The Shuttle radar topography mission: a new class of digital elevation models acquired by spaceborne radar, ISPRS J. Photogramm., 57, 241262, https://doi.org/10.1016/S0924-2716(02)00124-7, 2003.

Racoviteanu, A. E., Paul, F., Raup, B. H., Khalsa, S. J. S., and Armstrong, R.: Challenges and recommendations in mapping of glacier parameters from space: results of the 2008 Global Land Ice Measurements from Space (GLIMS) workshop, Boulder, Colorado, USA, Ann. Glaciol., 50, 53-69, https://doi.org/10.3189/172756410790595804, 2009.

Rosen, P. A., Hensley, S., Joughin, I. R., Li, F. K., Madsen, S. N., Rodriguez, E., and Goldstein, R. M.: Synthetic aperture radar interferometry, Proc. IEEE, 88, 333-385, https://doi.org/10.1109/5.838084, 2000.

Sakai, A. and Fujita, K.: Correspondence: Formation conditions of supraglacial lakes on debris-covered glaciers in the Himalaya, J. Glaciol., 56, 177-181, https://doi.org/10.3189/002214310791190785, 2010.

Shangguan, D., Liu, S., Ding, Y., Zhang, Y., Li, J., Li, X., and $\mathrm{Wu}, \mathrm{Z}$.: Changes in the elevation and extent of two glaciers along the Yanglonghe River, Qilian Shan, China, J. Glaciol., 56, 309317, https://doi.org/10.3189/002214310791968566, 2010.

Shangguan, D. H., Bolch, T., Ding, Y. J., Kröhnert, M., Pieczonka, T., Wetzel, H. U., and Liu, S. Y.: Mass changes of Southern and Northern Inylchek Glacier, Central Tian Shan, Kyrgyzstan, during $\sim 1975$ and 2007 derived from remote sensing data, The Cryosphere, 9, 703-717, https://doi.org/10.5194/tc-9-703-2015, 2015.

Shi, Y. and Liu, S.: Estimation on the response of glaciers in China to the global warming in the 21st century, Chinese Sci. Bull., 45, 668-672, https://doi.org/10.1007/BF02886048, 2000.

Shi, Y., Huang, M., and Ren, B.: An Introduction to the Glaciers in China, Science Press, Beijing, China, 1988.

Shi, Y., Liu, S., Shangguan, D., Li, D., Ye, B., and Shen, Y.: Two peculiar phenomena of climatic and glacial variations in the Tibetan Plateau, Adv. Clim. Change Res., 2, 154-160, 2006.

Shi, Y., Huang, M., Yao, T., and He, Y.: Glaciers and Related Environments in China, Science Press, Beijing, China, 2008a.

Shi, Y., Liu, S., Ye, B., Liu, C., and Wang, Z.: Concise Glacier Inventory of China, Shanghai Popular Science Press, Shanghai, China, 2008b.

$\mathrm{Su}, \mathrm{Z}$., Zhao, J., and Zheng, B.: Distribution and features of the glaciers' ELAs and the decrease of ELAs during the Last Glaciation in China, J. Glaciol. Geocryol., 36, 9-19, 2014.

Sun, M., Liu, S., Yao, X., Guo, W., and Xu, J.: Glacier changes in the Qilian Mountains in the past half century: based on the revised First and Second Chinese Glacier Inventory, Acta Geogr. Sin., 70, 1402-1414, 2015.

Surdyk, S.: Using microwave brightness temperature to detect short-term surface air temperature changes in Antarctica: an analytical approach, Remote Sens. Environ., 80, 256-271, https://doi.org/10.1016/S0034-4257(01)00308-X, 2002.

Wang, S., Zhang, M., Li, Z., Wang, F., Li, H., Li, Y., and Huang, X.: Response of glacier area variation to climate change in Chinese 
Tianshan mountains in the past 50 years, Acta Geogr. Sin., 66, 38-46, 2011.

Wei, J., Liu, S., Guo, W., Yao, X., Xu, J., Bao, W., and Jiang, Z.: Surface-area changes of glaciers in the Tibetan Plateau interior area since the 1970 s using recent Landsat images and historical maps, Ann. Glaciol., 55, 213-222, https://doi.org/10.3189/2014AoG66A038, 2014.

Wei, J., Liu, S., Guo, W., Xu, J., Bao, W., and Shangguan, D.: Changes in glacier volume in the north bank of the Bangong Co basin from 1968 to 2007 based on historical topographic maps, SRTM, and ASTER stereo images, Arct. Antarct. Alp. Res., 47, 301-311, https://doi.org/10.1657/AAAR00C-13-129, 2015a.

Wei, J.-F., Liu, S.-Y., Xu, J.-L., Guo, W.-Q., Bao, W.-J., Shangguan, D.-H., And Jiang, Z.-L.: Mass loss from glaciers in the Chinese Altai Mountains between 1959 and 2008 revealed based on historical maps, SRTM, and ASTER images, J. Mt. Sci., 12, 330-343, https://doi.org/10.1007/s11629-014-3175-1, 2015 b.

Werner, C., Wegmüller, U., Strozzi, T., and Wiesmann, A.: Gamma SAR and interferometric processing software, in: ERS-ENVISAT Symposium, 16-20 October 2000, Gothenburg, Sweden. Proceedings, edited by: Sawaya-Lacoste, H., European Space Agency, Noordwijk, 9 pp., digital media, available at: https://www.gamma-rs.ch/uploads/media/2000-1_ GAMMA_Software.pdf (last access: 20 March 2017), 2001.

Wu, K., Liu, S., Guo, W., Wei, J., Xu, J., Bao, W., and Yao, X.: Glacier change in the western Nyainqentanglha Range, Tibetan Plateau using historical maps and Landsat imagery: 1970-2014, J. Mt. Sci., 13, 1358-1374, https://doi.org/10.1007/s11629-0163997-0, 2016.

Wu, K., Liu, S., Bao, W., and Wang, R.: Remote sensing monitoring of the glacier change in the Gangrigabu Range, southeast Tibetan Plateau from 1980 through 2015, J. Glaciol. Geocryol., 39, 24 34, 2017.

$\mathrm{Xu}$, J., Liu, S., Zhang, S., Guo, W., and Wang, J.: Recent changes in glacial area and volume on Tuanjiefeng Peak region of Qilian Mountains, China, PLoS ONE, 8, e70574, https://doi.org/10.1371/journal.pone.0070574, 2013.

Yang, W., Yao, T., Xu, B., Wu, G., Ma, L., and Xin, X.: Quick ice mass loss and abrupt retreat of the maritime glaciers in the Kangri Karpo Mountains, southeast Tibetan Plateau, Chinese Sci. Bull., 53, 2547-2551, https://doi.org/10.1007/s11434-008-02883, 2008.

Yang, W., Yao, T., Xu, B., Ma, L., Wang, Z., and Wan, M.: Characteristics of recent temperate glacier fluctuations in the Parlung Zangbo River basin, southeast Tibetan Plateau, Chinese Sci. Bull., 55, 2097-2102, https://doi.org/10.1007/s11434-010-32144, 2010

Yang, K., Wu, H., Qin, J., Lin, C., Tang, W., and Chen, Y.: Recent climate changes over the Tibetan Plateau and their impacts on energy and water cycle: a review, Global Planet. Change, 112, 79-91, https://doi.org/10.1016/j.gloplacha.2013.12.001, 2014.
Yao, T., Thompson, L., Yang, W., Yu, W., Gao, Y., Guo, X., Yang, X., Duan, K., Zhao, H., Xu, B., Pu, J., Lu, A., Xiang, Y., Kattel, D. B., and Joswiak, D.: Different glacier status with atmospheric circulations in Tibetan Plateau and surroundings, Nat. Clim. Change, 2, 663-667, https://doi.org/10.1038/nclimate1580, 2012.

Yao, X., Liu, S., Guo, W., Huai, B., Sun, M., and Xu, J.: Glacier change of Altay Mountain in China from 1960 to 2009 - based on the Second Glacier Inventory of China, J. Nat. Resour., 27, 1734-1745, 2012.

Yao, X., Liu, S., Zhu, Y., Gong, P., An, L., and Li, X.: Design and implementation of an automatic method for deriving glacier centerlines based on GIS, J. Glaciol. Geocryol., 37, 1563-1570, 2015.

Ye, Q., Bolch, T., Naruse, R., Wang, Y., Zong, J., Wang, Z., Zhao, R., Yang, D., and Kang, S.: Glacier mass changes in Rongbuk catchment on Mt. Qomolangma from 1974 to 2006 based on topographic maps and ALOS PRISM data, J. Hydrol., 530, 273 280, https://doi.org/10.1016/j.jhydrol.2015.09.014, 2015.

You, Q., Kang, S., Pepin, N., Flügel, W.-A., Yan, Y., Behrawan, H., and Huang, J.: Relationship between temperature trend magnitude, elevation and mean temperature in the Tibetan Plateau from homogenized surface stations and reanalysis data, Global Planet. Change, 71, 124-133, https://doi.org/10.1016/j.gloplacha.2010.01.020, 2010.

Zhang, Y., Fujita, K., Liu, S., Liu, Q., and Nuimura, T.: Distribution of debris thickness and its effect on ice melt at Hailuogou glacier, southeastern Tibetan Plateau, using in situ surveys and ASTER imagery, J. Glaciol., 57, 1147-1157, https://doi.org/10.3189/002214311798843331, 2011.

Zhang, Z., Liu, S., Wei, J., Xu, J., Guo, W., Bao, W., and Jiang, Z.: Mass change of glaciers in Muztag Ata-Kongur Tagh, eastern Pamir, China from 1971/76 to 2013/14 as derived from remote sensing data, PLoS ONE, 11, e0147327, https://doi.org/10.1371/journal.pone.0147327, 2016a.

Zhang, Z., Xu, J.-L., Liu, S.-Y., Guo, W.-Q., Wei, J.-F., and Feng, T.: Glacier changes since the early 1960s, eastern Pamir, China, J. Mt. Sci., 13, 276-291, https://doi.org/10.1007/s11629-0143172-4, 2016b.

Zwally, H. J., Li, J., Brenner, A. C., Beckley, M., Cornejo, H. G., DiMarzio, J., Giovinetto, M. B., Neumann, T. A., Robbins, J., Saba, J. L., Yi, D., and Wang, W.: Greenland ice sheet mass balance: distribution of increased mass loss with climate warming; 2003-07 versus 1992-2002, J. Glaciol., 57, 88-102, https://doi.org/10.3189/002214311795306682, 2011. 